UNIVERSIDADE DE SÃO PAULO

ESCOLA DE ENGENHARIA DE SÃO CARLOS

CEZAR CARVALHO DE ARRUDA

Processos de Hidroxilação do Óxido de magnésio (MgO): Sínter e Magnésia Cáustica

São Carlos

2014 

CEZAR CARVALHO DE ARRUDA

\section{Processos de Hidroxilação do Óxido de magnésio (MgO): Sínter e Magnésia Cáustica}

Dissertação apresentada ao programa de Pós-Graduação em Ciência e Engenharia de Materiais da Universidade de São Paulo, para obtenção do título de Mestre em Ciências.

Área de concentração: Desenvolvimento, Caracterização e Aplicação de Materiais.

Orientador: Dr. Rafael Salomão

\section{São Carlos}




\section{AUTORIZO A REPRODUÇÃO E DIVULGAÇÃO TOTAL OU PARCIAL DESTE TRABALHO, POR \\ QUALQUER MEIO CONVENCIONAL OU ELETRÔNICO, PARA FINS DE ESTUDO E PESQUISA, DESDE QUE CITADA A FONTE.}

Arruda, Cezar Carvalho de

A779p Processos de Hidroxilação do Óxido de magnésio (MgO): Sínter e Magnésia Cáustica / Cezar Carvalho de Arruda; Dr. Rafael Salomão. São Carlos, 2014.

Dissertação (Mestrado - Programa de Pós-Graduação em Ciência e Engenharia de Materiais e Área de Concentração em Desenvolvimento, Caracterização e Aplicação de Materiais)-- Escola de Engenharia de São Carlos da Universidade de São Paulo, 2014.

1. Óxido de magnésio. 2. Hidróxido de magnésio. 3. Hidroxilação.

4. Sínter. 5. Magnésia cáustica. I. Título. 


\section{FOLHA DE JULGAMENTO}

Candidato: Bacharel CEZAR CARVALHO DE ARRUDA.

Título da dissertação: "Processos de hidroxilação do óxido de magnésio (MgO): sínter e magnésia cáustica".

Data da defesa: 19/02/2014

\section{Comissão Julgadora:}

Prof. Associado Rafael Salomão (Orientador)

(Escola de Engenharia de São Carlos/EESC)

Dr. Caue Ribeiro de Oliveira

(Embrapa)

Prof. Dr. Eduardo Bellini Ferreira

(Escola de Engenharia de São Carlos;EESC)

\section{Resultado:}
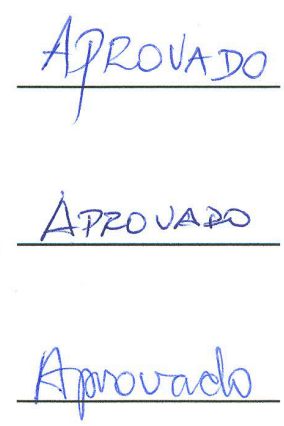

Coordenador do Programa de Pós-Graduação em Ciências e Engenharia de Materiais: Prof. Titular Waldek Wladimir Bose Filho

Presidente da Comissão de Pós-Graduação:

Prof. Titular Denis Vinicius Coury 


\section{AGRADECIMENTOS}

\section{AGRADECIMENTOS}

Ao professor Dr. Rafael Salomão pela atenção e apoio durante o processo de definição e orientação, que nos anos de convivência, muito me ensinou, contribuindo para meu crescimento científico e intelectual.

À Escola de Engenharia de São Carlos e á USP pela oportunidade de realização do curso de mestrado.

À Coordenação de Aperfeiçoamento de Pessoal de Nível Superior, pela concessão da bolsa de mestrado.

À Fundação de Amparo à Pesquisa do Estado de São Paulo e ao Conselho Nacional de Desenvolvimento Científico e Tecnológico pelo apoio financeiro para a realização desta pesquisa.

Enfim, a todos que de uma forma ou outra estiveram envolvidos na realização desde trabalho e na participação desta etapa da minha vida, os meus sinceros agradecimentos.

Muito obrigada a todos! 
Se, a princípio, a ideia não é absurda, então, há esperança para ela.

Albert Einstein 


\section{RESUMO}

Arruda, C. C. Processos de Hidroxilação do Óxido de magnésio (MgO): Sínter e Magnésia Cáustica 79p. Dissertação (Mestrado) -Escola de Engenharia de São Carlos, Universidade de São Paulo, São Carlos, 2014.

A principal limitação do uso de $\mathrm{MgO}$ em refratários é a facilidade com que reage com água formando hidróxido de magnésio $\left(\mathrm{Mg}(\mathrm{OH})_{2}\right)$ que, devido à sua menor densidade, causa tensões destrutivas nesses materiais. Para outras aplicações, no entanto, a reação de hidroxilação do $\mathrm{MgO}$ é necessária, como em produção de agentes antichamas, em compósitos poliméricos e na correção de pH de solos. Observações empíricas na literatura demonstraram que diferentes fontes de $\mathrm{MgO}$ possuem reatividades e sensibilidades à hidroxilação distintas. Este estudo analisou o impacto de variáveis externas (por exemplo, a liberação de calor que ocorre durante a reação ou o volume das amostras) que ainda não foi completamente compreendido. $O$ impacto auto-catalítico da temperatura reacional e da exotermia da reação foi avaliado. Por meio de medidas de temperatura in situ e de grau de hidroxilação termogravimétrico, também foram estudados os impactos do volume das amostras testadas e da concentração de sólidos nas suspensões, por meio de medidas de temperatura in situ e termogravimetria. Analisou-se também as principais diferenças estruturais entre duas principais fontes de $\mathrm{MgO}$ (sínter de $\mathrm{MgO}$ e magnésia cáustica): morfologia de partículas, densidade e área superficial específica. Em seguida, os mecanismos de hidroxilação em suspensões aquosas e seus efeitos foram avaliados por meio de testes de hidroxilação seguidos de termogravimetria, difração de raios- $X$, medidas de condutividade iônica, densidade, área superficial específica e microscopia eletrônica, e relacionado com as características físico-químicas e morfológicas das respectivas fontes de MgO. Pôdese constatar que diferenças significativas entre a temperatura nominal do meio reacional e no interior da amostra podem afetar a cinética de hidroxilação do material. $O$ volume e a concentração de sólidos variáveis também podem acentuar consideravelmente os efeitos da exotermia e gerar gradientes de hidroxilação. Também se verificou que a morfologia e a quantidade do $\mathrm{Mg}(\mathrm{OH})_{2}$ formado mudam significativamente dependendo do precursor e em função das condições de tempotemperatura.

Palavras-chave: óxido de magnésio, hidróxido de magnésio, hidroxilação, sínter, magnésia cáustica. 


\begin{abstract}
Arruda, C. C. Process of Hydroxylation of Magnesium Oxide (MgO): Sinter and Caustic Magnesia 79p. Dissertação (Mestrado) -Escola de Engenharia de São Carlos, Universidade de São Paulo, São Carlos, 2014.
\end{abstract}

The use of $\mathrm{MgO}$ in refractories is restrict due to the easy reaction with water forming magnesium hydroxide $(\mathrm{Mg}(\mathrm{OH}) 2)$. Its lower density causes compressive stresses that can crack their structure. On the other hand, for applications such as the production of flame retardant agents for polymer composites and $\mathrm{pH}$ correcting of contaminated soil, this reaction is necessary. Empirical observations in the literature have shown that different sources of $\mathrm{MgO}$ have district levels of chemical reactiveness. The present study analyzed the main structural differences between the two main sources of $\mathrm{MgO}$ (magnesia sinter and caustic magnesia): particle morphology, density and specific surface area. The mechanisms of hydroxylation of these raw materials in aqueous suspensions and their effects were followed by hydroxylation tests, X-ray diffraction, ionic conductivity, density, specific surface area and scanning electron microscopy. They were associated with the physical characteristics morphological, chemical of these $\mathrm{MgO}$ sourcesO. The impact of external variables (e.g., heat release during the reaction or the sample volume), that was not yet completely understood, was also evaluated through temperature measurements carried out in situ and hydroxylation degree accessed by thermogravimetry. The effects of samples' volume and solid concentration in aqueous suspension were also investigated. The results showed that differences between the ambient temperature and reaction inside sample temperature can affect the kinetics of hydroxylation of the material. The samples' volume and solids concentration can also enhance significantly the effects of heat release and generate gradients of hydroxylation. It was also found out that the morphology and the amount of $\mathrm{Mg}(\mathrm{OH}) 2$ formed can change depending on the precursor and on the timetemperature conditions.

Keywords: magnesium oxide, magnesium hydroxide, hydroxylation, sinter, caustic magnesia. 


\section{LISTA DE FIGURAS}

Figura 2.1 - Diagrama de um cristal plano de MgO pseudomórfico depois de ser produzido utilizando $\mathrm{O}^{\mathrm{MgCO}_{3}} \mathrm{em}$ baixas temperaturas de calcinação. (Figura adaptada da referência [26]).

Figura 2.2 - Mecanismo de hidroxilação do MgO policristalino. (Figura adaptada da referência [39]. 33

Figura 2.3 - As áreas de cinza representam o material sólido do corpo poroso. As áreas vazias estão preenchidas pelo material ainda em solução e cristais em crescimento. As figuras sólidas pretas, dentro dos poros, representam o crescimento rápido dos cristais aciculares. Apenas os dois cristais, que estão ligando o material sólido em forma de cunha e as paredes sólidas, irão provocar a ruptura dos elementos sólidos em forma de cunha. A avaria na ponta da cunha explica por que os produtos de degradação se transformam em pó. Esta ruptura também produz rachaduras e novas cunhas onde o processo pode continuar. (Figura adaptada da referência [33])

Figura 2.4: Efeito da presença de impurezas na velocidade de hidroxilação do MgO. (Figura adaptada da referência [39])

Figura 2.5: Efeito de recobrimento hidrofóbico na velocidade de hidroxilação do MgO. (Figura adaptada da referência [39])

Figura 3.1: Mecanismo utilizado para acompanhar a evolução de calor durante a reação.

Figura 3.2: Mecanismo utilizado para acompanhar a evolução de condutividade durante a reação.

Figura 4.1 - Imagens de MEV para partículas de magnésia caustica $(a, b)$ e sínter de $\mathrm{MgO}(\mathrm{c}, \mathrm{d})$ 
Figura 4.2 - Isotermas de adsorção física de $\mathrm{N}_{2}$ das matérias-primas, sínter (a) e magnésia cáustica (b). .52

Figura 4.3 - Imagens de MEV que mostram a transformação morfológica das partículas do sínter durante a reação de hidroxilação na temperatura de $50^{\circ} \mathrm{C}$ .54

Figura 4.4 - Imagens de MEV que mostram detalhes da morfologia das partículas do sínter durante a reação de hidroxilação na temperatura de $50^{\circ} \mathrm{C}$ 55

Figura 4.5 - DRX da evolução da reação de hidroxilação do sínter, ao longo de 7 dias, a $50^{\circ} \mathrm{C} .(\mathrm{P}=$ Periclásio, JCPDS $=45-0946 ; \mathrm{B}=$ Brucita, JCPDS = 07-0239). $\mathrm{Mg}(\mathrm{OH})_{2}$ de alta pureza (Synth, Brasil) é mostrado como referência .56

Figura 4.6 - Imagens de MEV que mostram a transformação morfológica das partículas da magnésia cáustica durante o seu processo de hidroxilação. .58

Figura 4.7 - Imagens de MEV que mostram detalhes da morfologia das partículas da magnésia cáustica durante a reação de hidroxilação na temperatura de $50^{\circ} \mathrm{C}$ 59

Figura 4.8 - DRX da evolução da reação de hidroxilação da magnésia cáustica, ao longo de 7 dias, a 50 C. $(\mathrm{P}=$ Periclásio, JCPDS = 45-0946; $\mathrm{B}=$ Brucita, JCPDS = 070239). 60

Figura 4.9 - Grau de hidroxilação e densidade do MgO em diferentes temperaturas nominais. a) magnésia cáustica $30^{\circ} \mathrm{C}$ e b) magnésia cáustica $50^{\circ} \mathrm{C}$. .61

Figura 4.10 - Grau de hidroxilação e densidade do MgO em diferentes temperaturas nominais. a) sínter $30^{\circ} \mathrm{C}$ e b) sínter $50^{\circ} \mathrm{C}(d)$ .62

Figura 4.11 - Temperatura da amostra de MgO com diferentes temperaturas nominais para a magnésia cáustica (a) e para o sínter (b). Parâmetros $\mathrm{T}_{\text {MAX }}$ e TT $_{\text {MAX }}$ para a magnésia cáustica (c) e para o sínter (d). 63 
Figura 4.12 - Grau de hidroxilação do MgO para suspensões com diferentes frações de sólidos com as matérias-primas magnésia cáustica e sínter. 65

Figura 4.13 - Temperatura da amostra de $\mathrm{MgO}$ mantendo fixo a temperatura nominal de $50^{\circ} \mathrm{C}$, volume de $45 \mathrm{~cm}^{3}$ e o período de 1 dia, mas em diferentes frações de sólidos com as matérias-primas magnésia cáustica (a) e sínter (b). 65

Figura 4.14 - Condutividade das suspensões do sínter em diferentes temperaturas. 67

Figura 4.15 - Condutividade das suspensões da magnésia cáustica em diferentes temperaturas. 68

Figura 4.16 - Condutividade das suspensões da magnésia cáustica a $70^{\circ} \mathrm{C}$ em diferentes concentrações de sólidos. 69

Figura 4.17 - Grau de hidroxilação do MgO (magnésia cáustica) em diferentes volumes com uma temperatura nominal de $30^{\circ} \mathrm{C}$ (a) e de $50^{\circ} \mathrm{C}(\mathrm{b})$ 70

Figura 4.18 - Temperatura da amostra de MgO (magnésia cáustica) em diferentes volumes com uma temperatura nominal de $30^{\circ} \mathrm{C}$ (a) e de $50^{\circ} \mathrm{C}$ (b). Parâmetros $\mathrm{T}_{\text {MAX }}$ e $\mathrm{TT}_{\text {MAX }}$ em diferentes volumes com uma temperatura nominal de $30^{\circ} \mathrm{C}$ (c) e de $50^{\circ} \mathrm{C}$ (d) 
XVI 


\section{LISTA DE TABELAS}

Tabela 3.1: Características das matérias primas utilizadas.

.44

Tabela 3.2: Classificação das suspensões caracterizadas por condutivimetria.......48

Tabela 4.1: Valores da área superficial específica, do volume de poros e do tamanho médio de poros das matérias-primas sínter e magnésia cáustica. 52 
XVIII 


\section{LISTA DE SIGLAS}

ABNT Associação Brasileira de Normas Técnicas

ASE Área Superficial Específica

BET Método de Brunauer - Emmett - Teller para área superficial

DRX Difração de Raio - X

MEV Microscopia Eletrônica de Varredura

USP Universidade de São Paulo 
XX 


\section{LISTA DE SÍMBOLOS}

\%massa Porcentagem da massa de sólidos em relação à massa total da amostra

\%volumeMgO Porcentagem do volume de óxido de magnésio em relação ao volume total da amostra

$\mathrm{M}_{\mathrm{SECA}}$ Massa após secagem a $200^{\circ} \mathrm{C}$

M CALC Massa após calcinação a $900^{\circ} \mathrm{C}$

TMAX Temperatura máxima atingida durante o teste de hidroxilação do óxido de magnésio

$\mathrm{TT}_{\mathrm{MAX}}$ Tempo necessário para que a temperatura máxima seja atingida no teste de hidroxilação do óxido de magnésio

$W_{H}$ Grau de hidroxilação

$W_{\text {H-EXP }}$ Grau de hidroxilação experimental

W ${ }_{\text {H-Teórico }}$ Grau de hidroxilação teórico 
XXII 


\section{SUMÁRIO}

1 INTRODUÇÃO

2 REVISÃO BIBLIGRÁFICA.

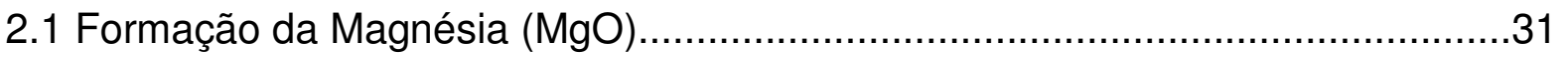

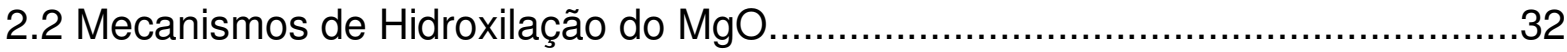

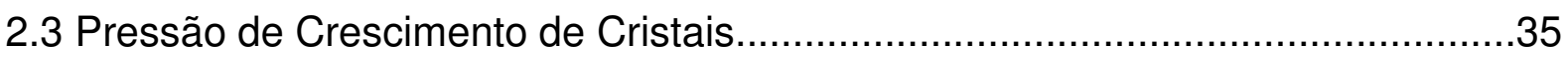

2.4 Quando a Hidroxilação do MgO é Útil..........................................................36

2.5 Quando a Hidroxilação do MgO é um Problema..............................................37

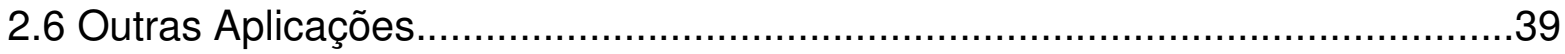

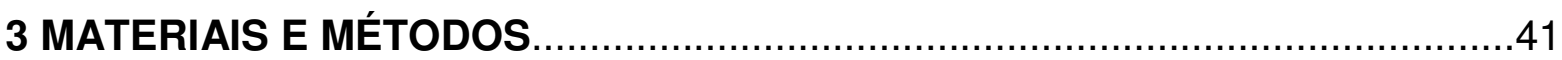

3.1 Técnicas de Caracterizção........................................................................

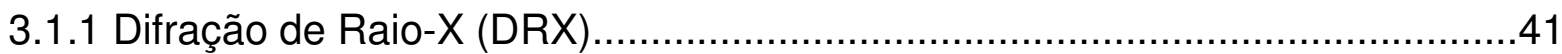

3.1.2 Microscopia Eletrônica de Varredura (MEV)..............................................41

3.1.3 Método de BET ou Teoria de Adsorção Multimolecular..................................41

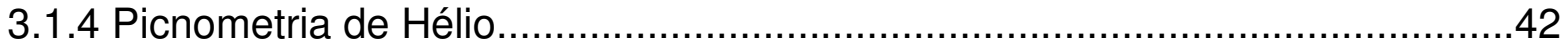

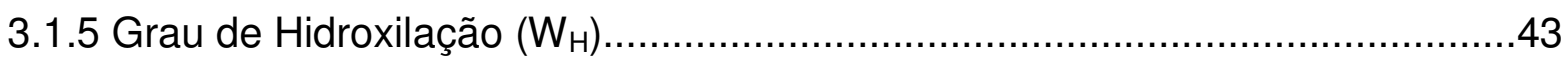

3.1.6 Condutivimetria lônica de Suspensões Aquosas de MgO..............................43

3.2 Caracterização das Matérias-primas............................................................ 44

3.3 Cinética de Hidroxilação das Matérias-primas................................................45

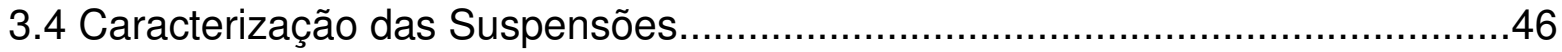

4 RESULTADOS E DISCUSSÃO

4.1 Caracterização das Matérias-primas como recebidas.......................................49 
4.2 Resultados da Reação de Hidroxilação utilizando as Matérias-primas Sínter e Magnésia Cáustica.

4.2.1 Morfologia e Cristalografia do Sínter.... 52

4.2.2 Morfologia e Cristalografia da Magnésia Cáustica........................................55

4.2.3 Densidade Real e Grau de Hidroxilação.....................................................59

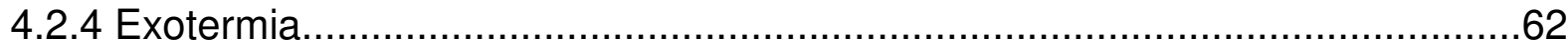

4.2.5 Resultados da Variação das Frações (\%massa) das Matériasprimas 63

4.2.6 Condutividade das Suspensões. 65

4.2.7 Resultados da Variação do Volume das Amostras de Magnésia Cáustica 68

5 CONCLUSÕES 71

REFERÊNCIAS .75 
XXVI 


\section{INTRODUÇÃO}

Tanto o óxido de magnésio ( $\mathrm{MgO}$ ou magnésia) como o hidróxido de magnésio $\left(\mathrm{Mg}(\mathrm{OH})_{2}\right.$ ou brucita) têm grande importância para as diversas atividades industriais, sendo empregados na indústria de refratários, na agropecuária, em aplicações poliméricas [1] até em sistemas anti-corrosão [2].

Outros usos importantes de magnésia incluem: adição de produtos químicos para o fabrico de cromo, olivina, a preparação de cimentos à base de oxicloretos de magnésio, farmacêuticos, fertilizantes, tintas e colas [3-5].

Investigações recentes têm-se centrado em torno do MgO "ativado". Estudos de taxas de reatividade do óxido de magnésio levaram à descoberta de que o processamento adequado pode desenvolver esses óxidos, de tal forma que eles sejam intensamente ativos, tanto física como quimicamente. Nestes estados ativados, a magnésia serve como um excelente adsorvente seletivo para uma variedade de materiais orgânicos. A magnésia ativa é usada extensamente na indústria petrolífera, na limpeza a seco, e nas indústrias de produtos químicos.

Devido à grande quantidade de formas de utilização do oxido de magnésio e do hidróxido de magnésio, formado a partir da hidroxilação do $\mathrm{MgO}$, essa reação tem despertado grande interesse tecnológico nas duas ultimas décadas, em alguns casos para evitá-la, em outros para torná-la mais eficiente.

Diversos estudos na literatura [2, 5-15] geraram resultados importantes, alguns deles são descritos a seguir, sobre a reação do $\mathrm{MgO}$ cristalino, também conhecido como periclasio, com a água $\left(\mathrm{H}_{2} \mathrm{O}\right)$, formando ou cristal $\left(\mathrm{Mg}(\mathrm{OH})_{2}\right)$.

Os cristais de brucita têm uma estrutura cristalina do tipo hexagonal e uma densidade de $2,4 \mathrm{~g} / \mathrm{cm}^{3}$. A diferença de densidade em relação à periclasio $(\rho=3,5$ $\mathrm{g} / \mathrm{cm}^{3}$ ), durante a hidroxilação, causa uma considerável expansão volumétrica que pode tencionar a estrutura, causando danos mecânicos como trincas, ou a rápida desintegração do material $[4,5,16]$.

$\mathrm{Na}$ literatura encontram-se dois mecanismos principais para a hidroxilação da magnésia. $O$ primeiro mecanismo, observado em menores temperaturas (abaixo de $90^{\circ} \mathrm{C}$ ), e baseado em um mecanismo de adsorção/precipitação [17] foi descrito em estudos voltados ao melhor controle da reação de hidroxilação para a utilização do 
$\mathrm{Mg}(\mathrm{OH})_{2}$ como aditivo anti-chama em materiais poliméricos. Nessas condições, a hidroxilação ocorre por meio de um processo de dissolução parcial das camadas superficiais do $\mathrm{MgO}$ e da saturação da suspensão com íons $\mathrm{Mg}^{2+}$ e $\mathrm{OH}^{-}$. Devido à baixa solubilidade desses íons em água de $\mathrm{pH}$ neutro, partículas de $\mathrm{Mg}(\mathrm{OH})_{2}$ rapidamente se precipitam na superfície das partículas e passam a atuar como núcleos de precipitação. Como a etapa de dissolução é mais lenta, a cinética de hidroxilação nessas condições é mais lenta do que em um meio hidrotermal.

$\mathrm{O}$ segundo ocorre em temperaturas que variam entre $135^{\circ} \mathrm{C}$ e $200^{\circ} \mathrm{C}$ (em condição hidrotermal), é conhecido como "shrinking core model" e foi proposto com base em estudos que visam a utilização do $\mathrm{MgO}$ em materiais refratários [5]. Os autores [3, 16-18] sugerem que a hidroxilação da magnésia policristalina (forma mais comum de magnésia comercial empregada em refratários) ocorra em duas etapas que se diferenciam, principalmente, pela velocidade de reação. Inicialmente, ocorre a formação de uma camada de hidróxido de magnésio na área dos contornos de grão (mais reativas, já que possuem maior energia livre), gerando um tencionamento na estrutura e o consequente microtrincamento da partícula. Esse efeito leva à formação de partículas cada vez menores e à exposição de áreas ainda não reagidas. Dessa forma, a área e a velocidade de reação aumentam de forma exponencial até que restem apenas as unidades cristalinas mais estáveis, de menor reatividade e recobertas por uma camada de hidróxido de magnésio. A partir desse momento, a velocidade da reação começa a diminuir e passa a ser governada apenas pela difusão de água através da camada de hidróxido.

Com base na revisão bibliográfica realizada [18-24], verificou-se uma ausência de estudos sistêmicos sobre o papel de algumas variáveis intrínsecas e externas na cinética de hidroxilação do $\mathrm{MgO}$, como o tipo de $\mathrm{MgO}$ (cáustica ou sínter) e a própria exotermia da reação, respectivamente. Devido a isso, este trabalho teve como objetivos principais estudar os mecanismos de hidroxilação do $(\mathrm{MgO})$ e avaliar as melhores condições para que ela ocorra de forma eficiente, quando necessário, ou seja evitada, caso não:

a) O efeito combinado do tempo e da temperatura do meio reacional na velocidade de hidroxilação, bem como na sua ação catalítica no processo. 
b) Os efeitos da concentração de sólidos na suspensão e o volume da amostra.

c) A estrutura cristalina e morfologia da matéria-prima utilizada na síntese de $\mathrm{Mg}(\mathrm{OH})_{2}$.

d) A condutividade das suspensões de óxido de magnésio em sua reação de hidroxilação.

Como objetivos acessórios, este trabalho também buscou auxiliar o Projeto Jovem Pesquisador FAPESP (Processo 2010/19274-5, "Novas Rotas de Síntese de Hidrotalcita para Uso em Cerâmicas Porosas para Isolamento Térmico em Altas Temperaturas") em que está inserido por meio das seguintes ações:

e) Determinar as condições mais favoráveis à hidroxilação do MgO que podem favorecer a formação de Hidrotalcita.

f) Aprimorar as ferramentas para acompanhamento da cinética de reações entre partículas reativas em suspensões aquosas.

g) Co-orientação de alunos de Iniciação Científica. 


\section{REVISÃO BIBLIOGRÁFICA}

\subsection{Formação da Magnésia (MgO)}

A magnésia $(\mathrm{MgO})$ é produzida para fins industriais principalmente por calcinação de magnesita $\left(\mathrm{MgCO}_{3}\right)$. Dependendo das condições térmicas (velocidade e temperatura máxima atingida), a magnésia cáustica ou sínter são obtidas. A magnésia cáustica é obtida a temperaturas relativamente baixas, e comparativamente é um material mais poroso e reativo. Têm muitas aplicações industriais, tais como na agricultura, alimentação do gado, controle ambiental, produção de cimentos especiais e em outros usos especiais. O sínter, produzido em altas temperaturas $\left(1200-1600^{\circ} \mathrm{C}\right)$, é utilizado principalmente pela indústria de refratários. A taxa e a extensão da hidroxilação são fatores que afetam o desempenho funcional de ambos os tipos de magnésia. O grau de hidroxilação da magnésia em refratários, por exemplo, deve ser reduzido a fim de evitar a degradação do tijolo. Por outro lado, a hidroxilação deve ser favorecida quando o objetivo é a produção de hidróxido de magnésio $\left(\mathrm{Mg}(\mathrm{OH})_{2}\right)$. Em ambos os casos, é conveniente o desenvolvimento de procedimentos de teste para prever a extensão de hidroxilação de uma dada amostra de MgO.

Alguns autores [25] relacionam as condições da calcinação da magnesita (temperatura do forno e tempo de permanência), com a atividade/reatividade da magnésia e o comportamento de hidroxilação. A calcinação de compostos de magnésio ocorre em duas etapas distintas: (1) saída dos gases nas temperaturas de $300^{\circ} \mathrm{C}$ a $500^{\circ} \mathrm{C}$ (Figura 2.1), e (2) recristalização ou sinterização à temperatura acima de $900^{\circ} \mathrm{C}$. Em temperaturas de calcinação mais baixas, a saída dos gases gera uma estrutura porosa com uma alta área superficial interna e de grande reatividade (poder de adsorção). Zettlemoyer e Walker [15] relatam que as áreas de superfície ativas da magnésia, determinadas por meio de isotérmicas de adsorção de nitrogênio a baixas temperaturas, são elevadas: em torno de $200 \mathrm{~m}^{2} / \mathrm{g}$ [26]. Este dado de adsorção de nitrogênio mostra o quão importante é o estudo a respeito do tipo de matéria-prima a ser utilizada em determinadas aplicações. 


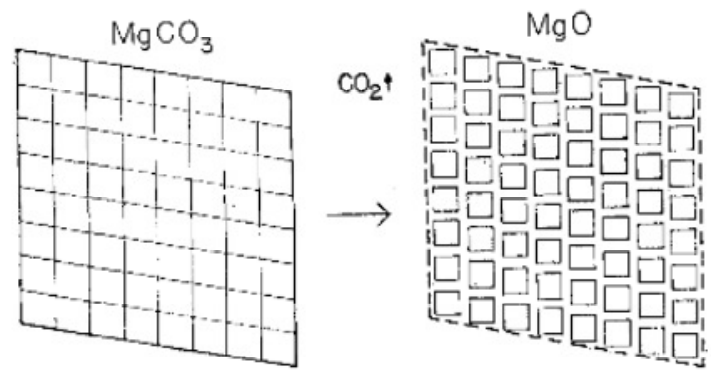

Figura 2.1 - Diagrama de um cristal plano de MgO depois de ser produzido utilizando o $\mathrm{MgCO}_{3}$ em baixas temperaturas de calcinação. (Figura adaptada da referência [26])

\subsection{Mecanismos de Hidroxilação do MgO}

Os mecanismos de hidroxilação do $\mathrm{MgO}$ têm sido estudados desde o século 19, no entanto, foi a partir da década de 1960 que eles se intensificaram [2, 5-7, 913, 27, 28]. A partir destes estudos estabeleceu-se que o mecanismo geral de reação ocorre em etapas: a dissolução da magnésia, com uma precipitação de hidróxido de magnésio. Verificou-se ainda que as propriedades físicas do reagente sólido podem influenciar fortemente a reação de hidroxilação. Em um dos primeiros estudos dirigidos à cinética da reação de hidroxilação do $\mathrm{MgO}$, Smithson e Bakhshi [14] concluíram que o modelo de encolhimento do núcleo não era adequado para descrever a hidroxilação das amostras de MgO. Kitamura et al. [5] propôs uma modificação das equações desse modelo clássico, incluindo um termo que incorpora a influência do produto depositado sobre o reagente sólido:

$$
\log r_{0}\left[1-(1-a)^{1 / 3}\right]=(1 / N) \log \left(t-t_{0}\right)+(1 / N) \log N K
$$

Onde $r_{0}$ é o raio médio da partícula, a é o grau de conversão de óxido para hidróxido, $t$ é o tempo de reação, to é o tempo de indução e $K$ é a razão entre a constante de reação e da densidade da partícula. A constante $N$ indica a influência do produto da reação pela inclusão de uma resistência adicional à reação $(\mathrm{N}=1$ pela reação e $\mathrm{N}=2$ por difusão) [23]. Outras propostas de hidroxilação do $\mathrm{MgO}$ 
consideram outras variáveis químicas como $\circ \mathrm{pH}$, e a evolução da reação em presença de outros reagentes, como $\circ \mathrm{CO}_{2}$ por exemplo [4, 5, 16, 29-31]. Considerando as duas reações que ocorrem, quando na presença de $\mathrm{CO}_{2}$, na hidroxilação do MgO, tem-se:

$$
\begin{gathered}
\mathrm{MgO}+\mathrm{H}_{2} \mathrm{O} \rightarrow \mathrm{Mg}(\mathrm{OH})_{2} \\
\mathrm{MgO}+\mathrm{H}_{2} \mathrm{O}+\mathrm{CO}_{2} \rightarrow \mathrm{MgO}+\mathrm{H}_{2} \mathrm{CO}_{3} \rightarrow \mathrm{MgCO}_{3}
\end{gathered}
$$

O produto da equação 2.2 é o hidróxido de magnésio ou cristal brucita, ele pode ser detectado por meio de difração de raios $X$ ou espetroscopia de infravermelho [29-31]. Esse processo causa um aumento do $\mathrm{pH}$ que favorece a dissolução de $\mathrm{CO}_{2}$ na água levando à formação de ácido carbônico, $\mathrm{H}_{2} \mathrm{CO}_{3}$. Esse ácido ataca o $\mathrm{MgO}$ formando carbonato de magnésio (equação 2.3), de aspecto similar a uma camada de bolor. Essa reação ocorre principalmente em sínteres estocados por longos tempos e em peças pré-moldadas expostas ao ar [29-31].

Devido à natureza policristalina da maioria dos óxidos de magnésio, o processo de hidroxilação geralmente ocorre em duas etapas [5]. Inicialmente, a região dos contornos de grão é preferencialmente atacada devido à sua maior energia livre. Quando a primeira camada de hidróxido se forma, sua expansão volumétrica gera tensões que rompem as ligações no contorno de grão (Figura 2.2). Esse processo ocorre durante o período conhecido como tempo de indução da hidroxilação e aumenta significativamente a área superficial disponível para reagir. Este processo leva a partículas cada vez menores, sendo as partículas de MgO quebradas até que restem somente monocristais. 


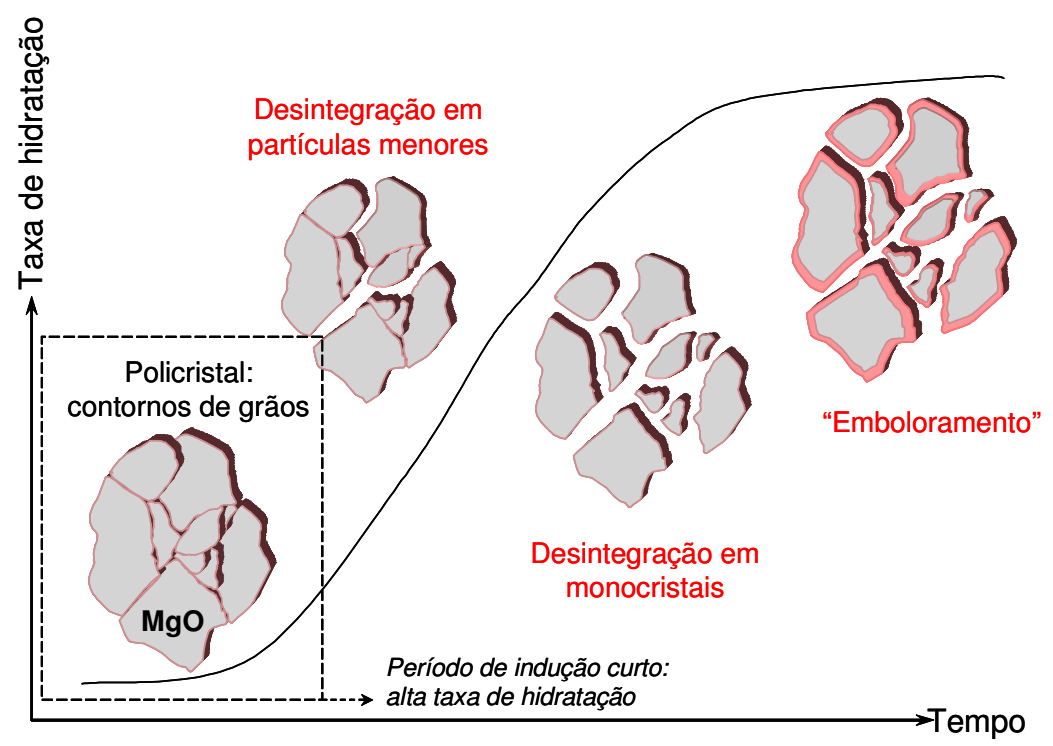

Figura 2.2 - Mecanismo de hidroxilação do MgO policristalino. (Figura adaptada da referência [39])

A tendência de se hidroxilar dos sínteres de MgO pode ser avaliada em testes de hidroxilação que consistem em expor esses materiais a diversas condições de umidade e temperatura, por diferentes períodos de tempo [5, 16, 18, 29-32]. Em seguida, o material é calcinado e a quantidade de produtos formados é comparada com o valor previsto pela estequiometria da reação. O grau de hidroxilação ( $\alpha$, de 0 a 1) pode ser calculado pela equação:

$$
\alpha=\left(\frac{\Delta m}{m_{i}}\right) \times\left(\frac{1}{0,45}\right)
$$

Onde $\Delta \mathrm{m}$ é variação de massa entre a amostra hidroxiladas e após a calcinação, $\mathrm{m}_{\mathrm{i}}$ é a massa inicial e o termo (1/0.45) é o valor teórico de $\alpha$ se a reação ocorresse de forma estequiométrica. Os produtos formados nos testes de hidroxilação podem ainda ser quantificados por meio de outras técnicas. A intensidade dos picos de difração de raios $X$, de espectroscopia de infravermelho e termogravimetria permitem identificar e quantificar a formação de brucita e magnesita [29-31]. 


\subsection{Pressão de Crescimento de Cristais}

Uma característica bastante conhecida da reação de hidroxilação do $\mathrm{MgO}$ é sua expansão volumétrica que pode causar danos mecânicos em sistemas densos como concretos refratários. Estudos [33] mostram que o processo de crescimento de cristais de $\mathrm{Mg}(\mathrm{OH})_{2}$ durante a hidroxilação interfere nas propriedades mecânicas do material. Nesse caso é de suma importância entender algumas inferências retiradas da literatura [32-35]. Alguns desses resultados podem ser listados da seguinte forma:

1) A temperatura de um cristal em crescimento em contato com uma solução supersaturada é maior do que a solução não concentrada. Esta diferença de temperatura é devido à liberação de calor da cristalização do cristal. Quanto mais rápida for à velocidade de crescimento do cristal, maior será essa diferença de temperatura.

2) $O$ habito do cristal em crescimento é determinado pela facilidade de dissipação do calor. O calor liberado se dissipa mais facilmente nas arestas ou nas pontas do que a partir de superfícies planas do cristal. Devido a isso, em taxas muito lentas de crescimento, aproximando-se das condições de equilíbrio isotérmicas o habito cristalino é assimétrico, levando a estruturas em formas de placas. Em taxas mais altas de crescimento, a forma tem de ser mais acicular e assimétrica.

3) Normalmente, um crescimento de cristal muito rápido pode ser conseguido utilizando uma solução altamente supersaturada. No entanto, isso nem sempre é verdade. Um exemplo foi apresentado [33], onde a taxa de crescimento é muito lenta, mesmo que o ambiente seja uma solução altamente supersaturada. Neste caso, os cristais simétricos formam-se a partir da solução altamente supersaturada.

4) Danos à matriz limitante são mais significativos quando o hábito de crescimento do cristal é acicular. Crescimentos simétricos tendem a causar menos danos, apesar de a solução ser supersaturada como no caso dos cristais aciculares. 
5) Ao considerar o mecanismo causador de dano, todos os fatores acima referidos têm de ser tidos em conta quantitativamente.

O mecanismo de danos proposto considerando-se a pressão de crescimento do cristal baseado nas inferências acima explicaria o colapso de materiais porosos, como no caso das partículas de magnésia cáustica. Na Figura 2.3 ilustra-se esquematicamente a principal característica desse mecanismo. Expansões rápidas e aciculares causam o colapso do material poroso. Este mecanismo é consistente com o pó formado a partir da degradação de um material.

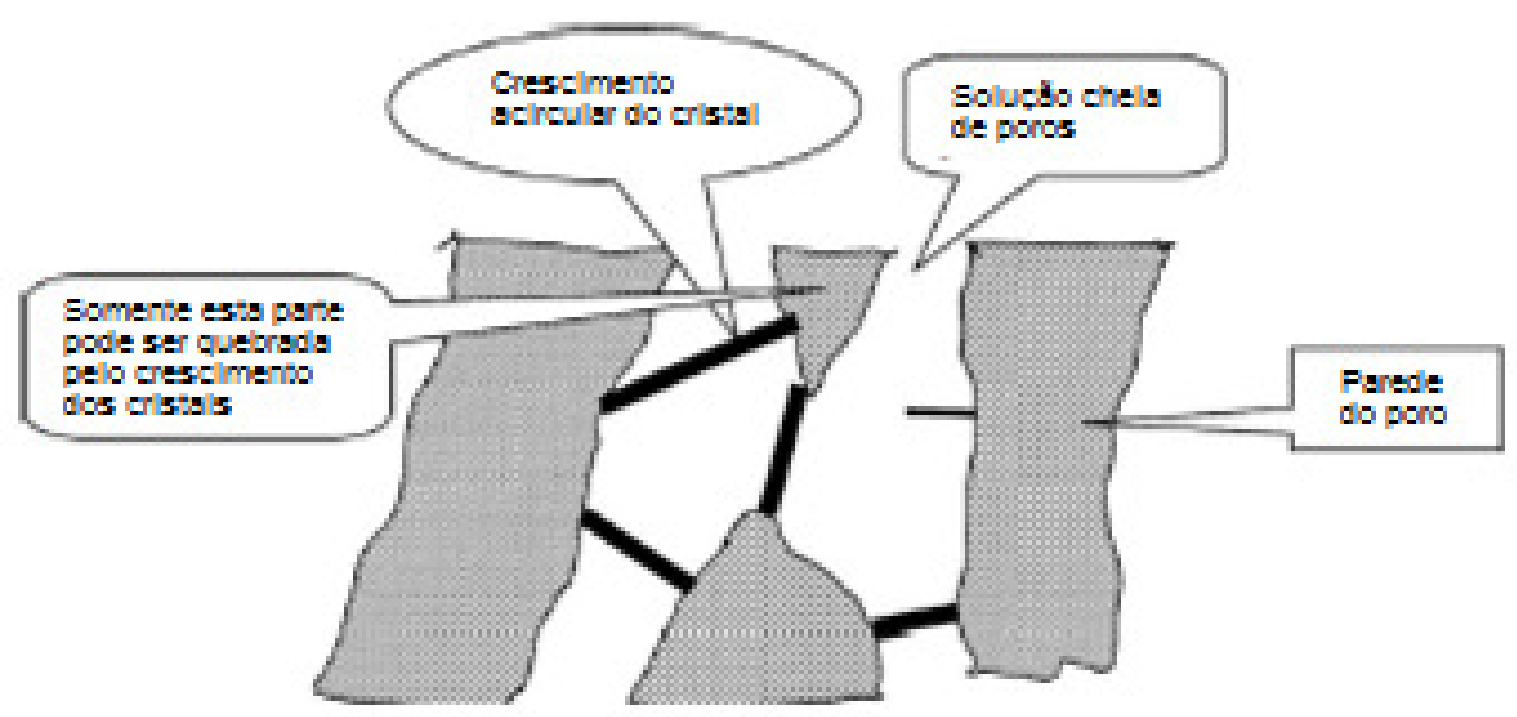

Figura 2.3 - As áreas de cinza representam o material sólido do corpo poroso. As áreas vazias estão preenchidas pelo material ainda em solução e cristais em crescimento. As figuras sólidas pretas, dentro dos poros, representam o crescimento rápido dos cristais aciculares. Apenas os dois cristais, que estão ligando o material sólido em forma de cunha e as paredes sólidas, irão provocar a ruptura dos elementos sólidos em forma de cunha. A avaria na ponta da cunha explica por que os produtos de degradação se transformam em pó. Esta ruptura também produz rachaduras e novas cunhas onde 0 processo pode continuar. (Figura adaptada da referência [33]) 


\subsection{Quando a Hidroxilação do MgO é Útil}

O hidróxido de magnésio é necessário em várias aplicações industriais, como para a produção de papel e celulose e nos campos de produtos farmacêuticos e tratamento de águas residuais, por exemplo. Nos últimos anos, foi observado também um interesse crescente relativo à utilização de pós de hidróxido de magnésio como retardador de chamas e aditivos supressores de fumaça para produzir compósitos poliméricos resistentes a incêndios [36, 37]. A aplicação do hidróxido de magnésio como um retardador de chama exige uma alta qualidade do $\mathrm{Mg}(\mathrm{OH})_{2}$ em pó no que diz respeito tanto à pureza química quanto às propriedades físicas do sólido tal como tamanho de partícula, área de superfície e morfologia.

O hidróxido de magnésio é geralmente obtido pela hidroxilação da magnésia, tal como indicado pela equação (2.2). A cinética da hidroxilação magnésia deve ser cuidadosamente controlada de modo a obter um hidróxido com as propriedades desejadas. De acordo com Fillipou et al [38], a hidroxilação muito rápida da magnésia irá resultar na formação de relativamente grandes agregados de hidróxido consistindo de cristalitos submicroscópicas com elevada área superficial, sendo esta morfologia de partícula inaceitável para certas aplicações. Além disso, a qualidade do hidróxido depende da qualidade do óxido de magnésio utilizado como precursor.

O mecanismo de reação da equação (2) compreende as etapas de dissolução de magnésio, seguida pela precipitação do hidróxido, já foram descritas na seção 2.2.1.

\subsection{Quando a Hidroxilação do MgO é um Problema}

O uso de óxido de magnésio ou magnésia $(\mathrm{MgO})$ na indústria de refratários tem uma série de vantagens como sua elevada refratariedade (ponto de fusão de $2800^{\circ} \mathrm{C}$ ) e boa resistência ao ataque por escórias alcalinas. Em combinação com óxido de alumínio $\left(\mathrm{Al}_{2} \mathrm{O}_{3}\right)$, pode levar à formação de espinélio $\left(\mathrm{MgAl}_{2} \mathrm{O}_{4}\right)$, que possui boa resistência ao choque térmico, além de custo competitivo. As vantagens 
técnicas aliadas aos aspectos econômicos tornaram-se a motivação de muitos estudos na área de refratários.

Apesar de todas essas vantagens, o uso de $\mathrm{MgO}$ em concretos refratários tem se limitado devido aos problemas relacionados principalmente com a sua elevada tendência a se hidratar. Pela expansão volumétrica causada pela hidroxilação do $\mathrm{MgO}[39,40]$ e devido a grande eficiência de empacotamento dos concretos, essa expansão, em geral, tensiona a estrutura, podendo causar danos mecânicos como trincas, ou o efeito conhecido como "dusting", ou seja, a rápida desintegração do concreto, que podem ocorrer durante as etapas de cura e secagem $[4,5,16]$. Essas limitações restringem a utilização de magnésia na formulação de concretos a no máximo $10 \%$ em massa e em granulometrias grosseiras (acima de $40 \mu \mathrm{m}$ ) [29].

Soluções que eliminem, reduzam ou contornem esses problemas podem levar ao desenvolvimento de concretos refratários com alto desempenho e durabilidade $[30,41]$. Algumas técnicas descritas na literatura sugerem formas de reduzir a velocidade de hidroxilação e seus efeitos nas propriedades dos refratários. Algumas delas são o controle das impurezas em MgO policristalino (Figura 2.4) [42] ou recobrimento das partículas de MgO com barreiras hidrofóbicas (Figura 2.5) [43, 44].

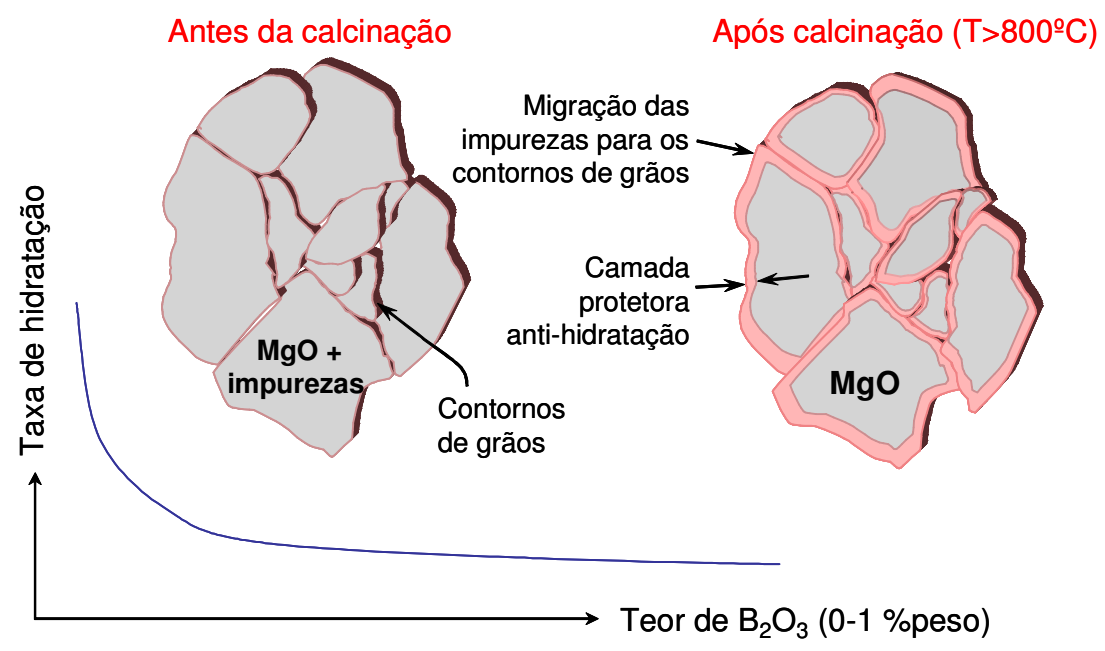

Figura 2.4: Efeito da presença de impurezas na velocidade de hidroxilação do MgO. (Figura adaptada da referência [39])

Como mostrado no mecanismo de hidroxilação de policristais (seção 2.2.1), contornos de grãos são regiões de elevada susceptibilidade à hidroxilação. $\mathrm{Na}$ 
tentativa de reduzir esse feito, impurezas de baixo ponto de fusão e com pouca ou nenhuma tendência a se hidratar (principalmente, $\mathrm{B}_{2} \mathrm{O}_{3}$, em teores até $1 \%$ peso) têm sido adicionadas em composições de $\mathrm{MgO}$ policristalino. Durante a calcinação $\left(900^{\circ} \mathrm{C}\right)$, as impurezas são expulsas e se fundem nos contornos, formando um recobrimento protetor (Figura 2.4).

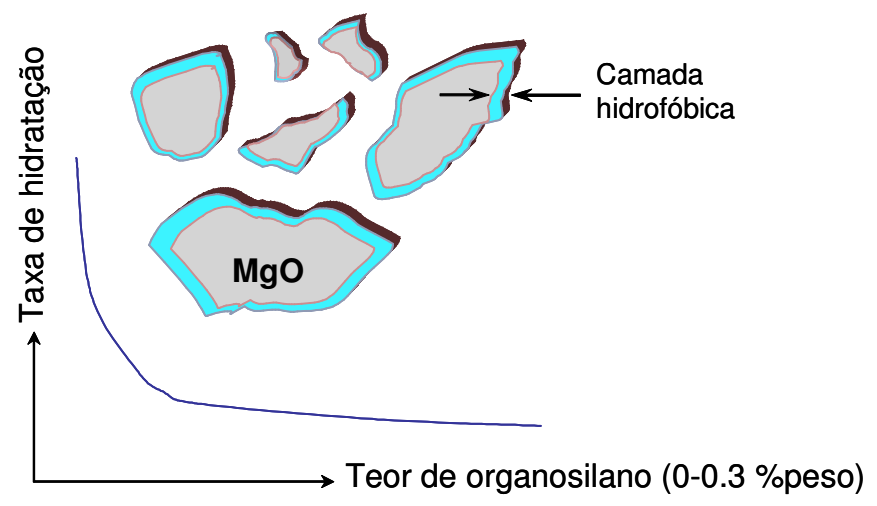

Figura 2.5: Efeito de recobrimento hidrofóbico na velocidade de hidroxilação do MgO. (Figura adaptada da referência [39])

Baseada no princípio de que sem água não pode ocorrer hidroxilação, a técnica consiste em tratar as partículas de $\mathrm{MgO}$ com organosilanos. Esses agentes promovem a formação de uma barreira contínua na superfície dos materiais tratados. Dependendo do tipo utilizado, ela pode ser hidrofílica ou hidrofóbica, como no caso do $\mathrm{MgO}$.

\subsection{Outras Aplicações}

Alguns trabalhos da literatura [2] relacionam a corrosão de metais com as taxas de dissolução dos produtos formados nas superfícies dos mesmos. Um estudo sobre a corrosão do alumínio [45] demonstrou uma nova compreensão dos fenômenos de corrosão, bem como novas formas de combatê-la. O comportamento da dissolução do $\mathrm{MgO}$ e $\mathrm{Mg}(\mathrm{OH})_{2}$ em uma variedade de soluções aquosas também demonstraram ser importantes para esta aplicação [2]. Algumas das características obtidas, relacionadas ao processo de hidroxilação do $\mathrm{MgO}$, nestes estudos são listadas a seguir: 
i) Cristais de $\mathrm{Mg}(\mathrm{OH})_{2}$ (brucita natural) dissolvem-se de forma limitada, quer por um reação de superfície ou pela incorporação de prótons; a remoção direta de $\mathrm{Mg}^{+2}$ e $\mathrm{OH}^{-}$a partir da solução parece ser feita de forma bem lenta. Este comportamento tem como consequência inibir a dissolução em vez de acelerar a difusão dos doadores de prótons, tais como ácidos carboxílicos ou oxiânions inorgânicos.

ii) O cristal de $\mathrm{Mg}(\mathrm{OH})_{2}$ parece sempre se dissolver a uma velocidade limitada, quer pela difusão de prótons para a superfície ou pela dissolução de espécies. O MgO se comporta como uma brucita em $\mathrm{pH}$ baixo e como $\mathrm{Mg}(\mathrm{OH})_{2}$ cristalino em $\mathrm{pH}$ maior. $\mathrm{O}$ óxido é provavelmente sempre coberto com uma fina camada de $\mathrm{Mg}(\mathrm{OH})_{2}$, e a sua taxa de dissolução é controlada pela dissolução de $\mathrm{Mg}(\mathrm{OH})_{2}$. 


\section{MATERIAIS E MÉTODOS}

\subsection{Técnicas de Caracterização}

\subsubsection{Difração de Raio-X (DRX)}

Todas as caracterizações por DRX deste trabalho foram realizadas pelo método pó em um difratometro RIGAKU ROTAFLEX modelo RV 200B, em $50 \mathrm{kV}$ e $100 \mathrm{~mA}$, com Cu igual a Ka e comprimento de onda $\lambda=1,542 \AA$. O programa banco de dados JCPDS foi usado para identificação das fases, com $2 \theta$ de $3^{\circ}$ até $100^{\circ}$ graus, com velocidade de varredura de por $2 \% \mathrm{~min}$.

\subsubsection{Microscopia Eletrônica de Varredura (MEV)}

As imagens de MEV, deste trabalho foram feitas em amostras em pó, dispersas a seco sobre uma fita condutora fixada à superfície do porta-amostras. Em seguida, fez-se a preparação da amostra com recobrimento de ouro de espessura de $20 \mathrm{~nm}$, aplicando-se a diferença de potencial de 5kV. O microscópico utilizado foi o de marca FEl, modelo Inspect ${ }^{\mathrm{TM}} \mathrm{F} 50$.

\subsubsection{Método de BET ou Teoria de Adsorção Multimolecular para a medida da Área Superficial Específica (ASE)}

O Método de BET ou ainda Teoria de Adsorção Multimolecular busca descrever a adsorção física de moléculas de gás sobre uma superfície sólida e serve como base para uma técnica de análise importante para medição de área superficial específica de um material e do volume de micro e mezzo poros em sua estrutura. 
Neste trabalho o método de BET foi utilizado para determinar a ASE das amostras (equipamento NOVA 1200e Surface Area \& Pore Size, Quantachrome Instruments, EUA, gás utilizado na analise: $\mathrm{N}_{2}$. Antes de cada medida, as amostras foram degasadas (i.e. cada célula contendo as amostras passaram por um processo de aquecimento em baixa pressão) a $200^{\circ} \mathrm{C}$ por 24 horas sobre um pressão de $1,36 \times 10^{-4} \mathrm{~atm}$. Para cada condição, 2 amostras equivalentes foram testadas utilizando-se os mesmos parâmetros.

\subsubsection{Picnometria de Hélio}

O picnómetro de gás determina o volume verdadeiro de um sólido (mesmo que poroso) por variação da pressão de gás numa câmara de volume conhecido (WEBB e ORR, 1997). Normalmente utiliza-se hélio porque este gás, além de inerte, penetra facilmente nos poros acessíveis da amostra, devido ao pequeno tamanho dos seus átomos. O picnometro de hélio é constituído por duas câmaras de volumes conhecidos (por calibração prévia): a câmara inicial onde se coloca a amostra e a câmara de expansão, ligadas por uma válvula (válvula de expansão). Antes de iniciar a análise propriamente dita, a amostra, colocada na câmara inicial, é sujeita a repetidas purgas com hélio, para remoção de impurezas e humidade que eventualmente possa conter.

A densidade real $\left(\mathrm{g} / \mathrm{cm}^{3}\right)$ de cada amostra foi medida pelo picnometro de Hélio (ULTRAPYC 1200e, Quantachrome Instruments, EUA), após um tratamento térmico de $100^{\circ} \mathrm{C}$ por 24 horas para que se eliminasse qualquer água residual das amostras. Cada valor de densidade é resultado do valor médio de cinco medições consecutivas realizadas pelo equipamento. 


\subsubsection{Grau de Hidroxilação $\left(\mathrm{W}_{\mathrm{H}}\right)$}

O grau de hidroxilação ( $\mathrm{W}_{\mathrm{H}-\mathrm{EXP}}$, \%massa) para cada combinação de tipo de $\mathrm{MgO}$, tempo e temperatura foi calculado utilizando-se a Equação 3.1;

$$
\mathrm{W}_{\mathrm{H}-\mathrm{EXP}}(\% \text { massa })=100 \% \times\left(\mathrm{M}_{\text {Seca }}-\mathrm{M}_{\text {Calc }}\right) / \mathrm{M}_{\text {Calc }}
$$

Utilizou-se como parâmetro de referência o grau de hidroxilação teórico $\left(\mathrm{W}_{\mathrm{H}}\right.$ Teórico $=44,67 \%$ ) que considera que a reação de hidroxilação-desidroxilação ocorreu estequiometricamente $\left(\mathrm{M}_{\text {Seca }}=\right.$ massa molecular do $\mathrm{Mg}(\mathrm{OH})_{2} 58,4 \mathrm{~g} / \mathrm{mol} ; \mathrm{M}_{\text {Calc }}=$ massa molecular do $\mathrm{MgO}=40,3 \mathrm{~g} / \mathrm{mol}$ ). O procedimento para a obtenção da $\mathrm{M}_{\text {Seca }} \mathrm{e}$ da $M_{\text {Calc }}$ para o cálculo do $W_{H}$ de cada amostra está descrito na secção 3.3.

\subsubsection{Condutivimetria lônica de Suspensões Aquosas de MgO}

A condutividade ou condutividade elétrica é definida como a capacidade de um material em estado sólido, líquido ou gasoso em conduzir corrente elétrica. $A$ capacidade de uma solução em conduzir corrente elétrica depende da presença de íons, da sua concentração, mobilidade e valência. Outro fator que influencia também a condutividade é a temperatura. Pode-se recorrer à medição da condutividade na água para se determinar concentrações de minerais ou outros tipos de íons. Assim a condutividade é uma medida da concentração de partículas ionizados presentes. Contudo, condutividade é apenas uma medição quantitativa, pois responde a qualquer conteúdo iónico e não consegue distinguir, em particular, materiais condutivos na presença de outros. Apenas materiais ionizáveis contribuem para a condutividade da água. Para medir a condutividade de uma solução aquosa, aplica-se uma corrente alternada a dois elétrodos inertes submersos numa solução e medir a tensão resultante ao longo da solução. Durante este processo, os cátions movimentam-se em direção ao elétrodo negativo enquanto os aníons são atraídos para o elétrodo positivo e assim a solução torna-se um condutor elétrico. A intensidade da corrente elétrica que atravessa a solução depende da resistência elétrica associada. 
O equipamento utilizado em todas as caracterizações de condutivimetria deste trabalho foi o condutivímetro marca: GEHAKA, modelo CG 2000, célula do sensor de condutividade do tipo eletrodo com constante de célula $K=10$.

\subsection{Caracterização das Matérias-primas}

Foram utilizadas duas fontes comerciais de $\mathrm{MgO}$ originalmente empregadas na produção de tijolos e concretos refratários para indústria siderúrgica: sínter de alta pureza (M30 de Alta Pureza, Magnesita Refratários S. A., Brasil) e Magnésia Cáustica (QMAG-AR200, Magnesita Refratários S. A., Brasil) (Tabela 3.1).

Tabela 3.1: Características das matérias primas utilizadas.

\begin{tabular}{ccc}
\hline \multirow{2}{*}{ Matérias-Primas } & \multicolumn{2}{c}{ Fontes de MgO } \\
\cline { 2 - 3 } & Cáustica $^{1}$ & Sínter $^{1}$ \\
\hline Composição $(\%$ massa, típica $)$ & $98,9 \%$ de $\mathrm{MgO}$ & $99,5 \%$ de $\mathrm{MgO}$ \\
Tamanho da partícula $\left(\mathrm{D}_{50} / \mathrm{D}_{90}, \mu \mathrm{m}\right)$ & $12 / 25$ & $5 / 10$ \\
Densidade $\left(\mathrm{g} / \mathrm{cm}^{3}\right)$ & 3,487 & 3,473 \\
Área superficial especifica $\left(\mathrm{m}^{2} / \mathrm{g}\right)$ & 17 & 1,5 \\
Tamanho de cristalito médio $\left(\mathrm{C}_{50}, \mu \mathrm{m}\right)^{*}$ & 12,8 & 3,6 \\
Umidade $\left(\% p e s o, 24 \mathrm{~h}\right.$ a $\left.110^{\circ} \mathrm{C}\right)$ & 1,2 & 0,8 \\
Perda de ignição $\left(\%\right.$ massa, $\left.110-1100^{\circ} \mathrm{C}\right)$ & 0,9 & 0,1 \\
\hline 1) Magnesita Refratários S. A., Brasil, ${ }^{*}$ valores típicos obtidos pela Equação de Scherrer \\
\hline
\end{tabular}

As duas materiais primas foram caracterizadas como recebidas utilizando-se as técnicas de difração de raio-x (para identificar as fases cristalinas presentes), microscopia eletrônica de varredura (morfologia das partículas), método de BET ou Teoria de Adsorção Multimolecular (área superficial específica), e picnometria de hélio (densidade real). 


\subsection{Cinética de Hidroxilação das Matérias-primas}

Suspensões aquosas de MgO (sínter ou magnésia cáustica) foram preparadas em pressão ambiente (0,94 atm.), contendo 53\%massa (24,3\%volume) em um misturador mecânico (PowerVisc, IKA, Alemanha), a 1000 rpm por 2 minutos. Com essas suspensões-base três conjuntos de experimentos foram preparados:

1) Uma alíquota de suspensão foi colocada no porta-amostras de $45 \mathrm{~cm}^{3}(38 \mathrm{x}$ $38 \mathrm{~mm})$ e mantida em temperatura constante $\left(30,40,50,60\right.$ e $\left.70 \pm 2^{\circ} \mathrm{C}\right)$ por até 168 h. Durante esse período, a temperatura da suspensão no interior do porta-amostra foi registrada continuamente a cada 10 segundos utilizando-se um termopar tipo $\mathrm{K}$. Uma amostra de referência inerte composta por uma suspensão de alumina calcinada (A2G, Alcoa Alumínio, Brasil, $D_{50}=7 \mu \mathrm{m}$ ) com granulometria equivalente e mesmo teor de sólidos foi utilizada para verificar os efeitos da inércia térmica do sistema e sua reprodutibilidade.

2) Diversas alíquotas da mesma suspensão foram colocadas em portaamostras individuais (Figura 3.1) e mantidas nas mesmas temperaturas constantes do caso anterior $\left(30-70 \pm 2^{\circ} \mathrm{C}\right)$. Em intervalos de $24 \mathrm{~h}$, alíquotas foram retiradas, secas a $200^{\circ} \mathrm{C}$ por $24 \mathrm{~h}\left(\mathrm{M}_{\text {Seca, }}, \mathrm{g}\right)$. Em seguida foram calcinadas a $900^{\circ} \mathrm{C}$ por $5 \mathrm{~h}$ e novamente pesadas $\left(\mathrm{M}_{\text {Calc }}\right)$.

3) Duas alíquotas de suspensão foram colocadas em porta-amostras cilíndricos (Figura 3.1). Em um conjunto de experimentos, variou-se o volume dos portaamostras de $45 \mathrm{~cm}^{3}(39 \times 39 \mathrm{~mm})$ até $382,5 \mathrm{~cm}^{3}(78 \times 78 \mathrm{~mm})$, sendo estas mantidas em temperatura constante $\left(30-50 \pm 2^{\circ} \mathrm{C}\right)$ por até $24 \mathrm{~h}$. Em outro, variou-se a concentração de sólidos nas suspensões de 36\%massa até 69\%massa, mantendose constantes as dimensões do porta-amostras em $45 \mathrm{~cm}^{3}$, a temperatura do ensaio em $50^{\circ} \mathrm{C} \pm 2^{\circ} \mathrm{C}$, o intervalo em $24 \mathrm{~h}$ e a matéria prima (cáustica). Durante esse período, a temperatura das suspensões no interior dos porta-amostras foi registrada continuamente a cada 10 segundos por um termopar do tipo K. Em intervalos de 24 $\mathrm{h}$, alíquotas foram retiradas, secas a $200^{\circ} \mathrm{C}$ por $24 \mathrm{~h}\left(\mathrm{M}_{\text {Seca }}, \mathrm{g}\right)$, sendo em seguida, calcinadas a $900^{\circ} \mathrm{C}$ por $5 \mathrm{~h}$ e novamente pesadas $\left(\mathrm{M}_{\text {Calc }}\right)$. 


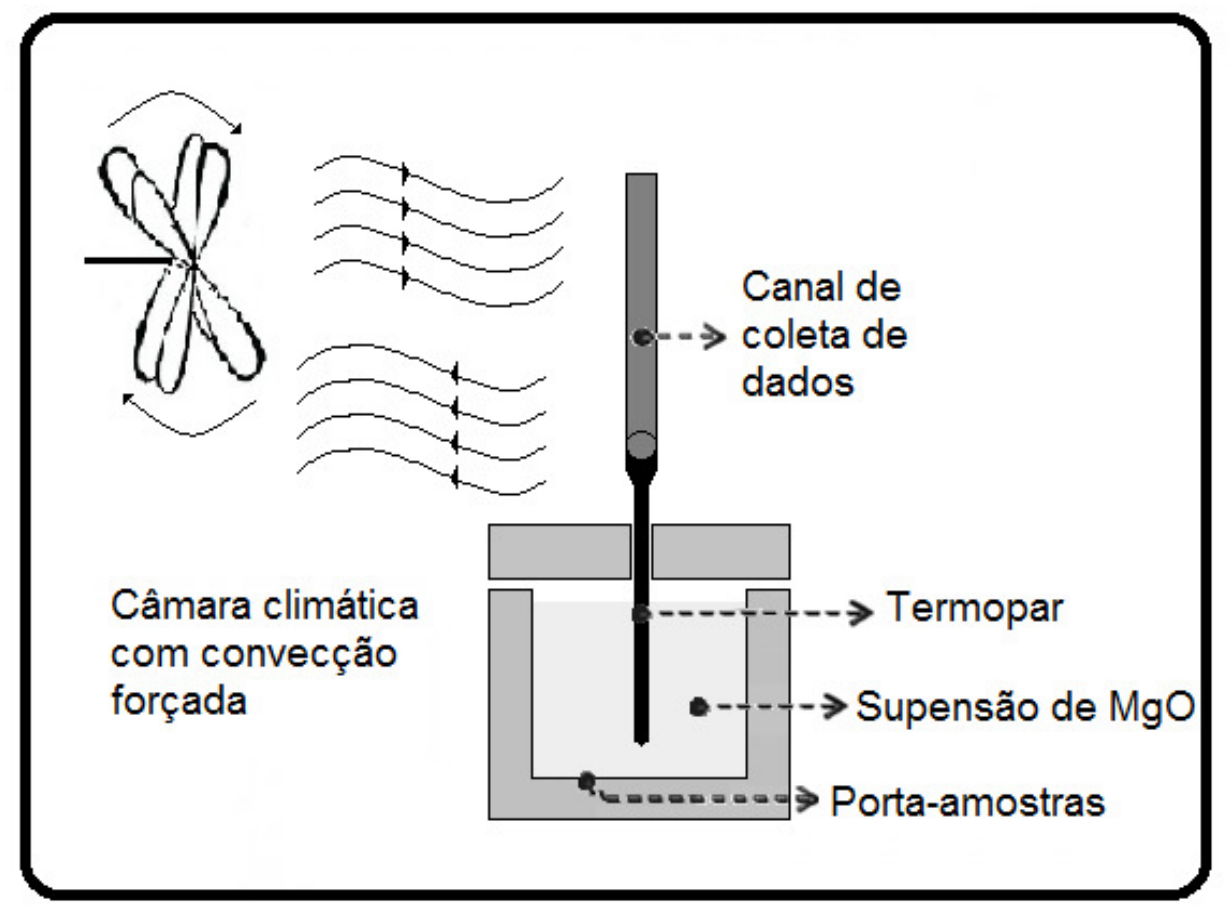

Figura 3.1: Mecanismo utilizado para acompanhar a evolução de calor durante a reação.

Esses resultados são mostrados na forma de curvas de temperatura da suspensão versus tempo de reação nas seções (4.2.4, 4.2 .5 e 4.2.7) e foram analisados utilizando-se dois parâmetros: a) a temperatura máxima atingida durante o teste ( $T_{\text {MAX }}$ ) que fornece o indicativo da extensão da reação (quantidade de $\mathrm{MgO}$ reagido) e b) o tempo para que essa temperatura seja atingida (TT $\mathrm{TAX}_{\mathrm{MAX}}$ ) que indica a reatividade do material (tempo necessário para o ápice da reação).

A densidade das amostras secas, após o teste de hidroxilação, foi medida por meio da picnometria de Hélio. Após as medições de densidade as amostras foram caracterizadas quanto a sua morfologia por meio de microscopia eletrônica de varredura, a sua área superficial especifica, e a identificação de fases pela difração de raio- $x$.

\subsection{Caracterização das Suspensões}

Suspensões foram preparadas em pressão ambiente (0,94 atm.), utilizando um aparato (Figura 3.2), com dimensões $800 \mathrm{~cm}^{3}$ e $(100 \times 100 \mathrm{~mm})$. Conforme a 
Tabela 3.2, diferentes matérias-primas, concentrações de sólidos e temperaturas foram utilizadas para a medição da condutividade iônica das suspensões utilizando a técnica da condutivimetria descrita na secção 3.1.6. Sendo o controle da homogeneização feito por meio do misturador mecânico (IKA) com 700 rotações por minuto. Os valores de condutividade iônica e temperatura foram coletados a cada 5 segundos.

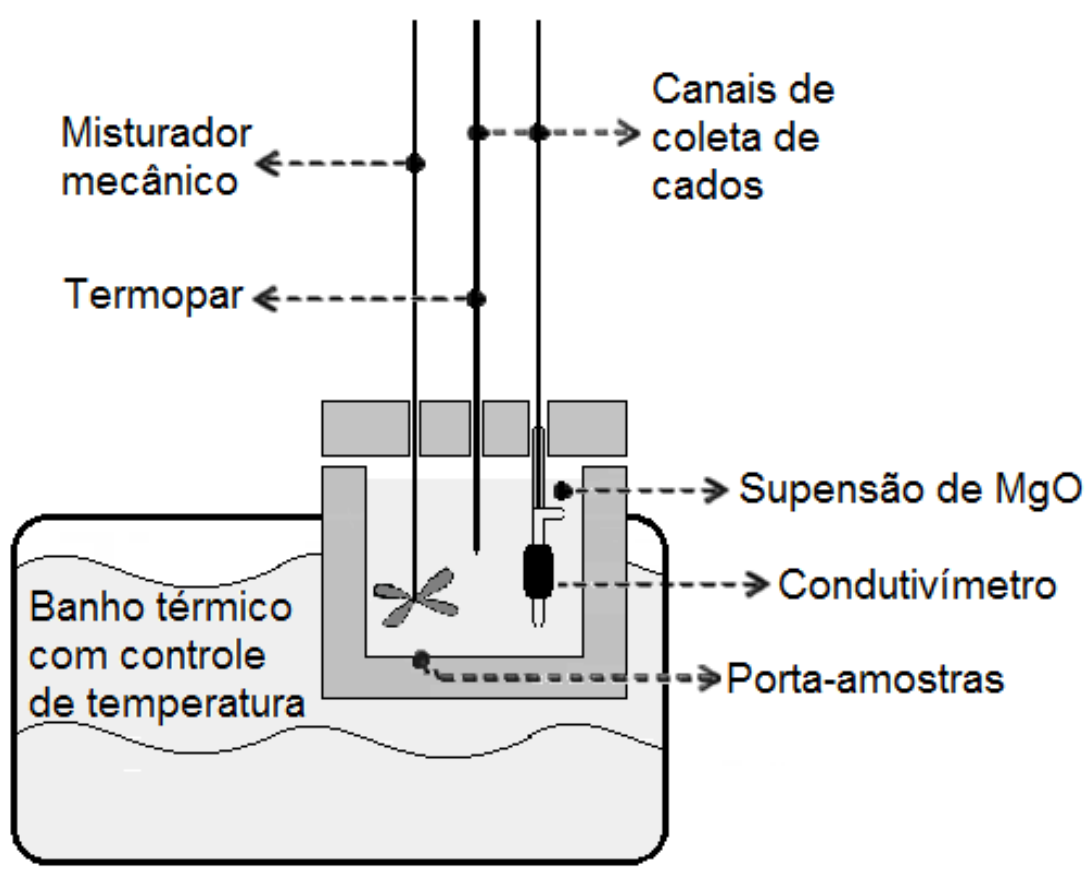

Figura 3.2: Mecanismo utilizado para acompanhar a evolução de condutividade durante a reação. 
Tabela 3.2: Classificação das suspensões caracterizadas por condutivimetria.

\begin{tabular}{ccc}
\hline Matéria-prima & Temperatura $\left({ }^{\circ} \mathbf{C}\right)$ & $\begin{array}{c}\text { Concentração } \\
\text { (\%massa)/(\%volumeMgO) }\end{array}$ \\
\hline Sínter & 10 & $35,8 / 13,8$ \\
& 30 & $35,8 / 13,8$ \\
& 50 & $35,8 / 13,8$ \\
& 70 & $35,8 / 13,8$ \\
Caustica & 10 & $35,8 / 13,8$ \\
& 30 & $35,8 / 13,8$ \\
& 50 & $35,8 / 13,8$ \\
& & $4,3 / 1,3$ \\
& & $8,6 / 2,6$ \\
& & $17,2 / 5,6$ \\
& & $35,8 / 13,8$
\end{tabular}




\section{RESULTADOS E DISCUSSÃO}

\subsection{Caracterização das Matérias-primas como recebidas}

Observa-se nas Figuras 4.1 a-b que as partículas da magnésia cáustica apresentaram uma superfície muito mais irregular que aquela observada para 0 sínter (Figura $4.1 \mathrm{c}-\mathrm{d}$ ). No primeiro caso, verifica-se que as partículas de magnésia cáustica possuem uma estrutura formada por unidades menores (da ordem de 100 $\mathrm{nm}$ ), fortemente agregadas e depositadas em camadas. A geometria dessas partículas decorre do processo de formação da magnesita, que foi depositada em camadas por processos naturais a partir de sedimentação de sais de magnésio. Já as pequenas unidades nanométricas são oriundas de trincas formadas durante 0 processo de descarbonatação da magnesita $\left(400-600^{\circ} \mathrm{C}\right)$, pela saída do $\mathrm{CO}_{2}$. Após calcinação e início da sinterização $\left(900-1200^{\circ} \mathrm{C}\right)$, a microestrutura microtrincada forma pequenas unidades individuais aproximadamente regulares, com grande porosidade interna (Tabela 4.1) e área superficial específica.

Para o sínter, as partículas são mais lisas e angulosas, devido, respectivamente, às maiores temperaturas empregadas na sua produção (acima de $1600^{\circ} \mathrm{C}$ ) e aos processos de moagem para ajuste granulométrico. Nesse caso, a sinterização em altas temperaturas permite que a estrutura microtrincada após a descarbonatação possa se recuperar, formando partículas densas e de baixa área superficial específica (ASE). Outra evidência desse efeito pode ser observada nas isotermas de adsorção (Figura 4.2): enquanto a magnésia cáustica possui grande quantidade de poros internos nas partículas (evidenciados pelo elevado volume de $\mathrm{N}_{2}$ adsorvido em $\mathrm{P} / \mathrm{P}_{0}=1$ ), o sínter praticamente não permite nenhuma adsorção de gás. É importante mencionar ainda que, para a magnésia cáustica, a área de histerese das isotermas de adsorção/dessorção é bastante reduzida, quando comparada a outros materiais mezoporosos (como zeólitas, por exemplo). Esse efeito indica que o elevado volume de adsorção está relacionado principalmente à elevada ASE e não à presença de micro e mesoporos. 

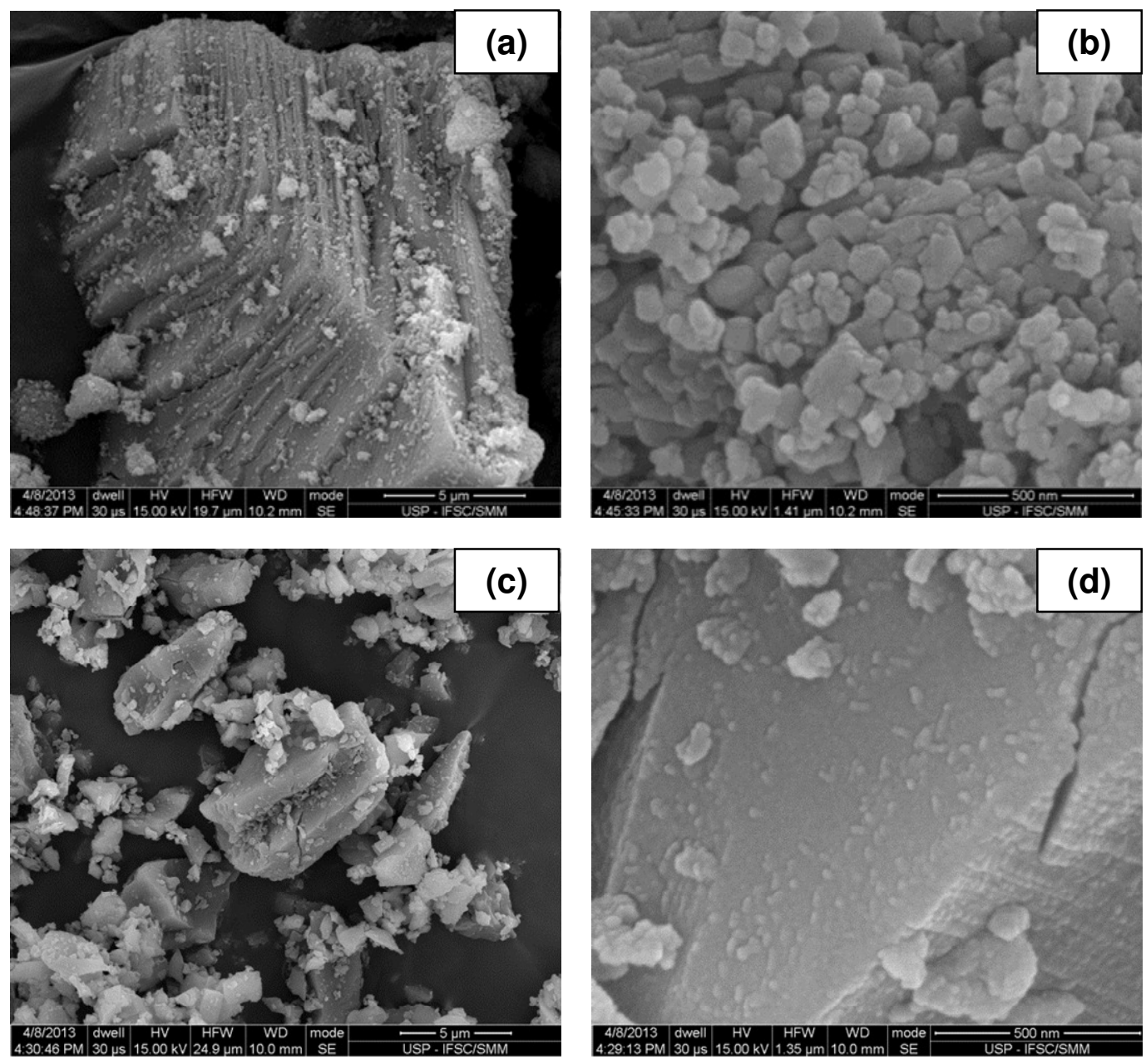

Figura 4.1 - Imagens de MEV para partículas de magnésia caustica $(a, b)$ e sínter de MgO (c,d). 


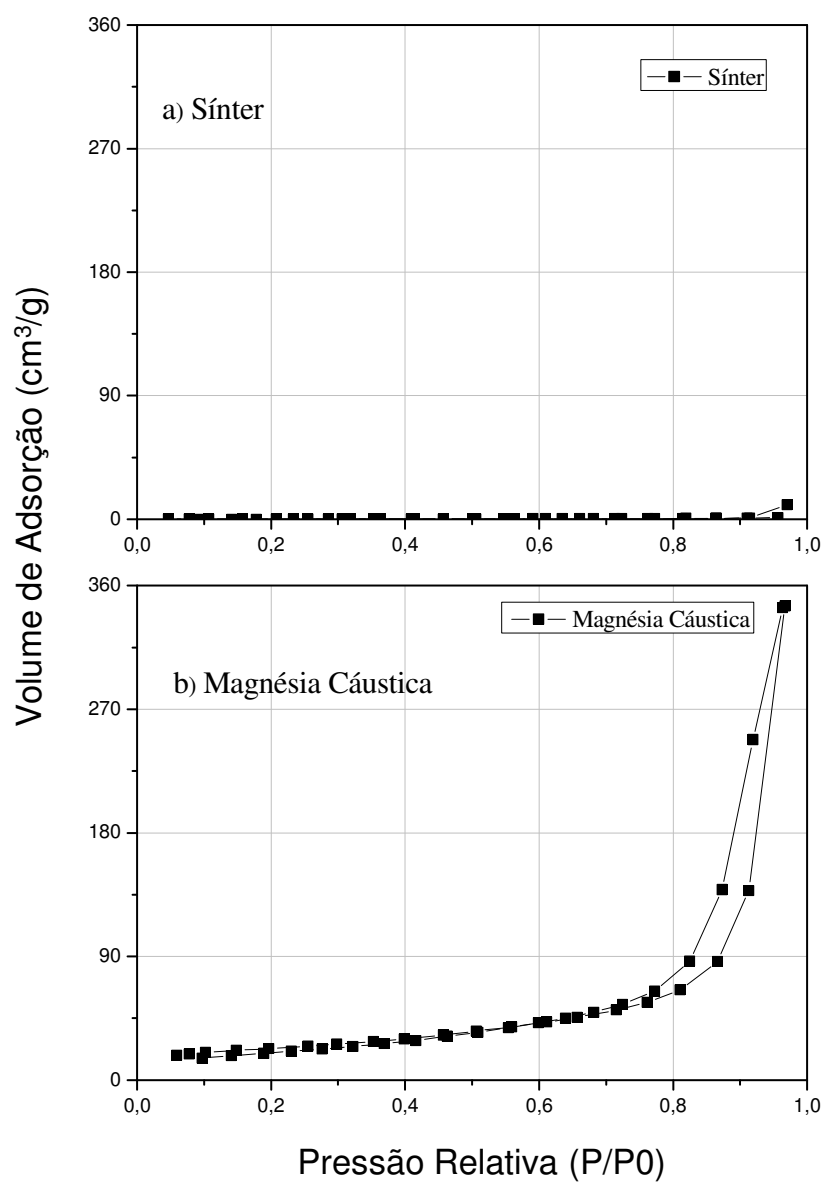

Figura 4.2 - Isotermas de adsorção física de $\mathrm{N}_{2}$ das matérias-primas, sínter (a) e magnésia cáustica (b)

Tabela 4.1: Valores da área superficial específica, do volume de poros e do tamanho médio de poros das matérias-primas sínter e magnésia cáustica.

\begin{tabular}{cccc}
\hline Matérias-Primas & $\begin{array}{c}\text { Área } \\
\text { Superficial } \\
\text { Especifica } \\
\left(\mathrm{m}^{2} / \mathrm{g}\right)\end{array}$ & $\begin{array}{c}\text { Volume de poros } \\
\left(\mathrm{cm}^{3} / \mathrm{g}\right)\end{array}$ & $\begin{array}{c}\text { Tamanho médio de poros } \\
(\AA)\end{array}$ \\
\hline Sínter & $1,5 \pm 0,3$ & $(2,8 \pm 0,2) \times 10^{-3}$ & $48 \pm 3$ \\
\hline $\begin{array}{c}\text { Magnésia } \\
\text { cáustica }\end{array}$ & $23 \pm 1$ & $(9 \pm 3) \times 10^{-2}$ & $82 \pm 27$ \\
\hline
\end{tabular}




\subsection{Resultados da Reação de Hidroxilação utilizando as Matérias-primas Sínter e Magnésia cáustica}

\subsubsection{Morfologia e Cristalografia do Sínter}

No inicio do processo de hidroxilação do sínter magnesiano, observa-se nos resultados de DRX que o processo de hidroxilação ocorre progressivamente ao longo do tempo, evidenciando pelo aumento da intensidade dos picos de difração da brucita e da redução e desaparecimento do $\mathrm{MgO}$ cúbico (Periclásio) que foi observado na identificação de fases (Figura 4.5). Observa-se ainda a fragmentação das partículas durante o curso da reação nas imagens de MEV (Figura 4.3 e 4.4) uma figura geométrica em forma de prisma triangular (mais evidente na Figura 4.4 (a)), até então não registrada na literatura. Também se constatou (Figura 4.3) que após 7 dias de reação do sínter, a $50^{\circ} \mathrm{C}$ em pressão ambiente de 0,94 atm., formouse placas ou lamelas a partir de cristais hexagonais, sendo que estas estruturas são as esperadas para a brucita [46]. 

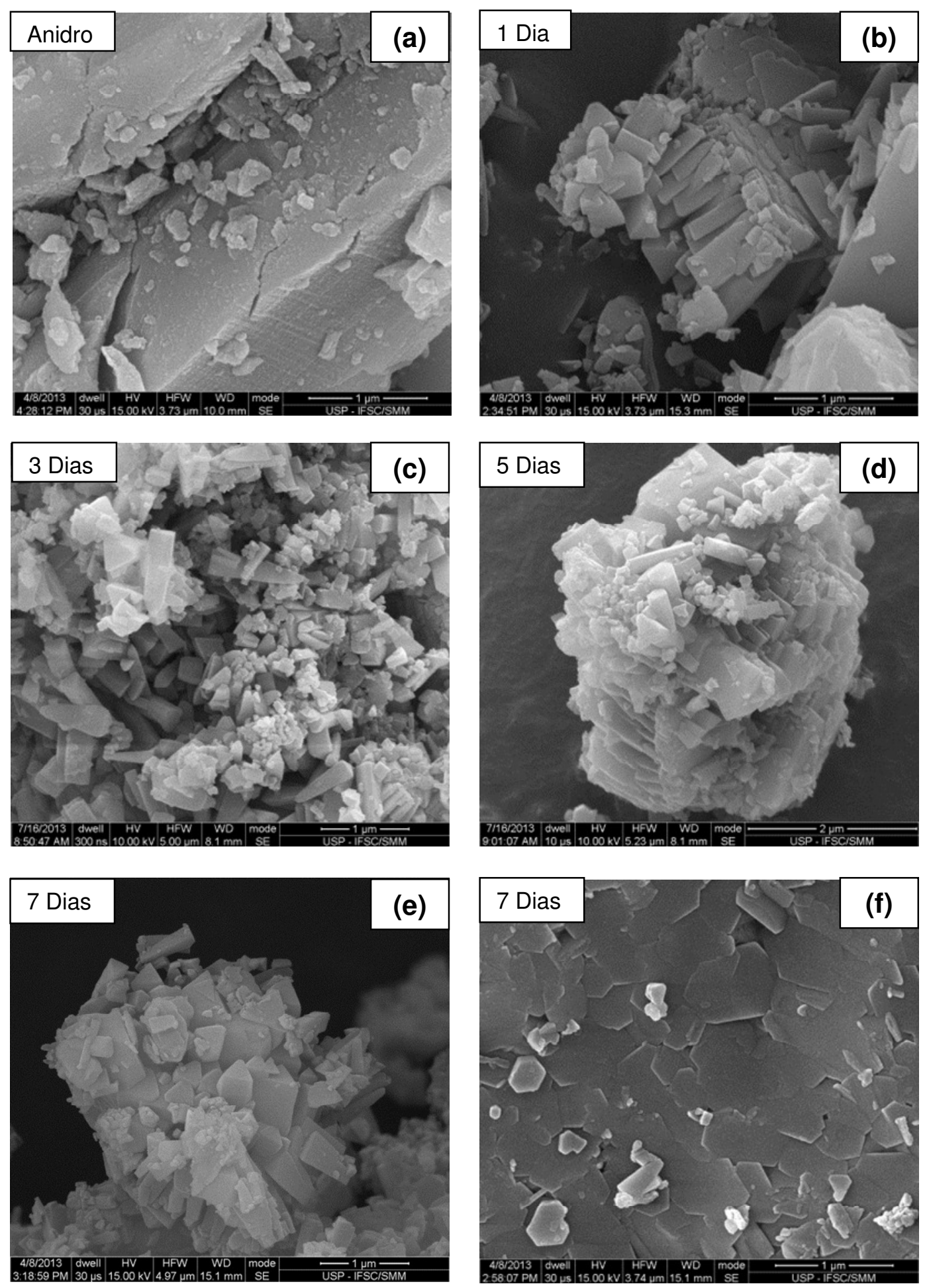

Figura 4.3 - Imagens de MEV que mostram a transformação morfológica das partículas do sínter durante a reação de hidroxilação na temperatura de $50^{\circ} \mathrm{C}$. 

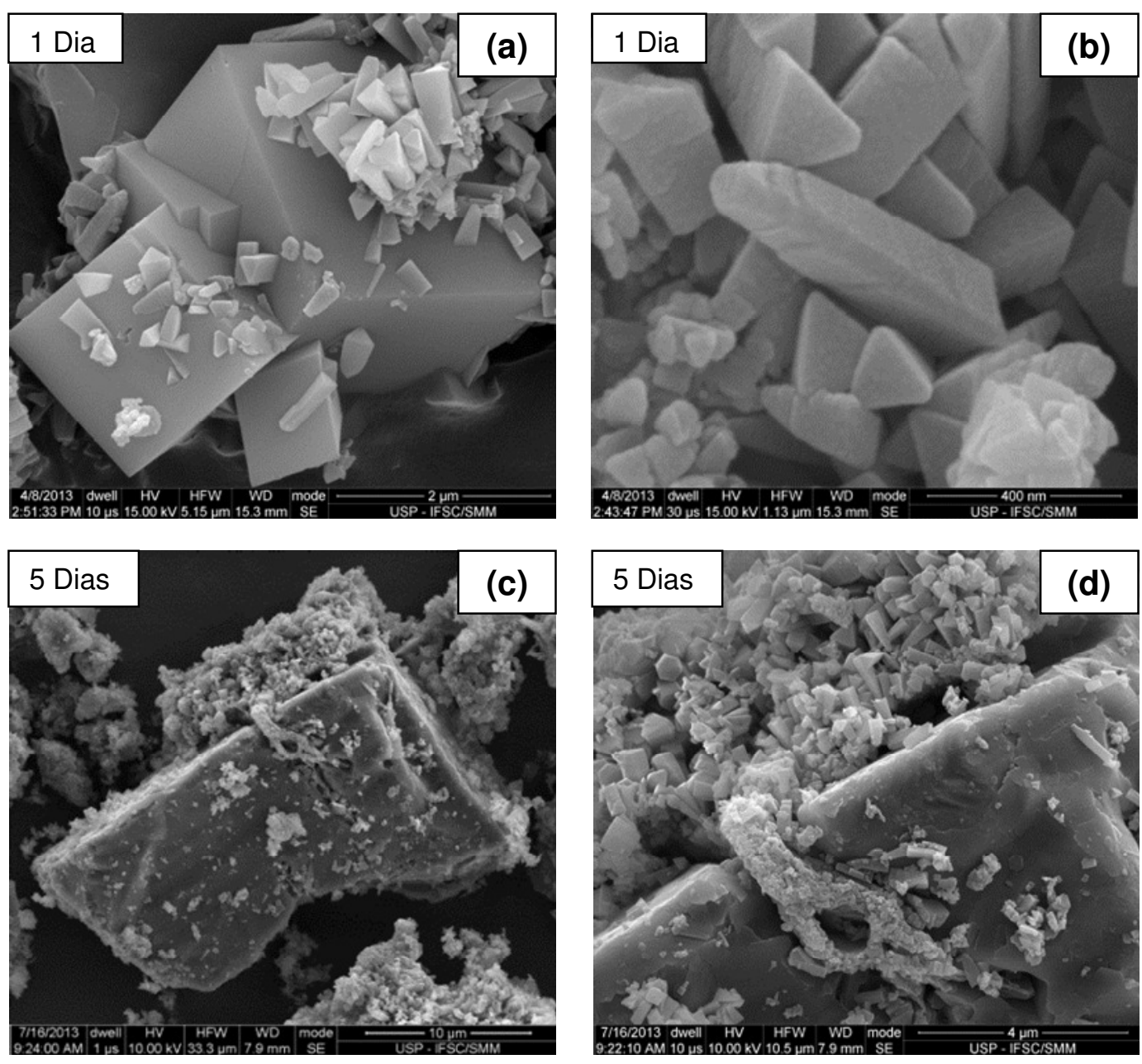

Figura 4.4 - Imagens de MEV que mostram detalhes da morfologia das partículas do sínter durante a reação de hidroxilação na temperatura de $50^{\circ} \mathrm{C}$. 


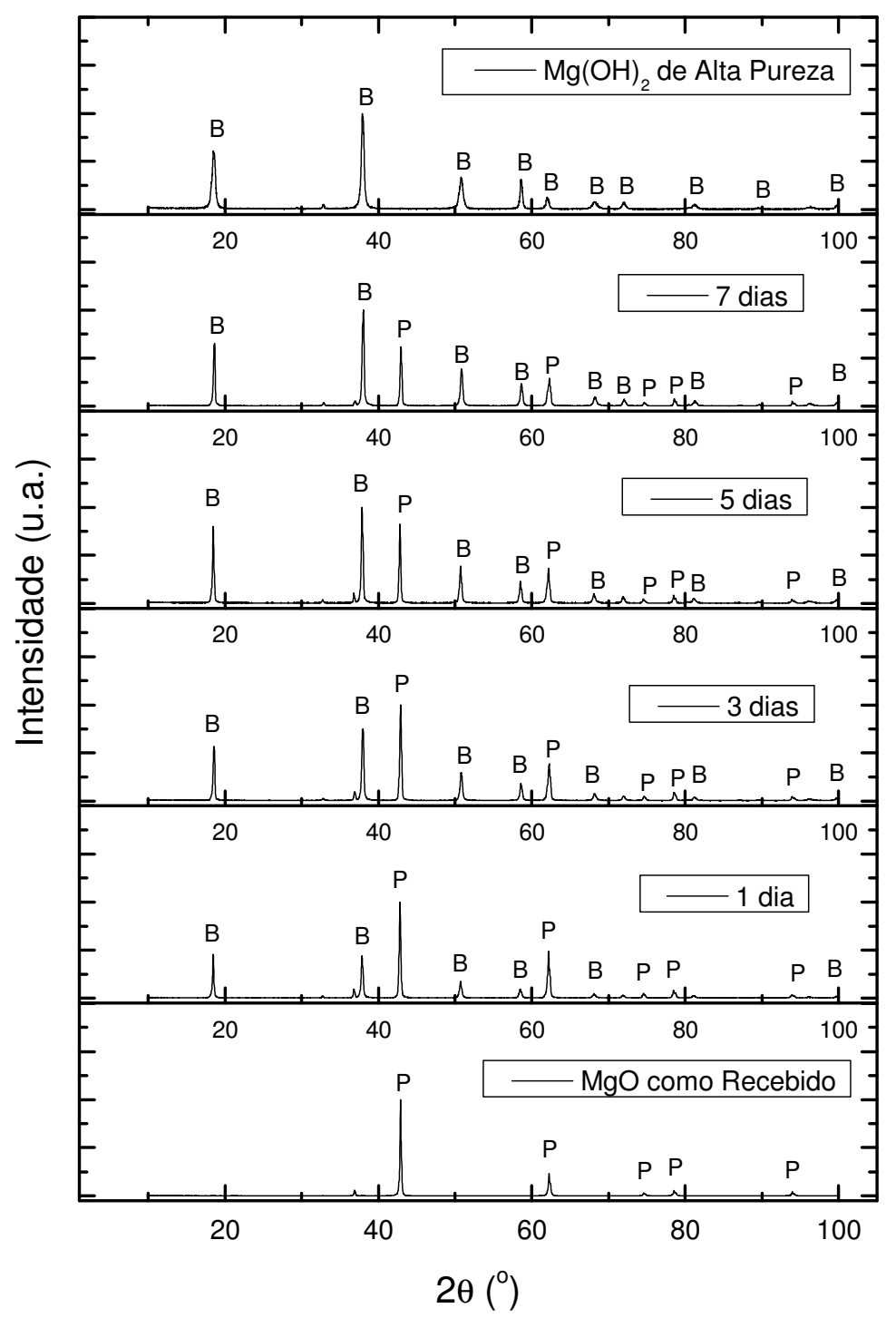

Figura 4.5 - DRX da evolução da reação de hidroxilação do sínter, ao longo de 7 dias, a $50^{\circ} \mathrm{C}$. $(\mathrm{P}=$ Periclásio, JCPDS = 45-0946; $\mathrm{B}=$ Brucita, JCPDS = 07-0239). $\mathrm{Mg}(\mathrm{OH})_{2}$ de alta pureza (Synth, Brasil) é mostrado como referência.

\subsubsection{Morfologia e Cristalografia da Magnésia Cáustica}

As imagens de MEV (Figuras 4.6 e 4.7) mostram uma diferença na morfologia dos cristais de $\mathrm{Mg}(\mathrm{OH})_{2}$ formados a partir do sínter e da magnésia cáustica. Enquanto, os cristais de brucita a partir do sínter mostram-se estarem crescendo 
(Figuras 4.3 e 4.4 - (a)), os da brucita a partir da magnésia cáustica podem ser visualizados bem definidos (Figura 4.6 - (b)) e com uma geometria hexagonal regular. Comparando os resultados de MEV com os do DRX da Magnésia cáustica, observa-se que os picos característicos do periclásio desaparecem logo após o 1 dia (Figura 4.8), sendo que, os picos da brucita surgem ainda no 1 dia. Este resultado confirma o teste de $\mathrm{W}_{\mathrm{H}}$ (Figura 4.9 - (b)) aonde se tem $90 \%$ de grau de hidroxilação, comparando-se com o valor máximo possível, que é o teórico. 

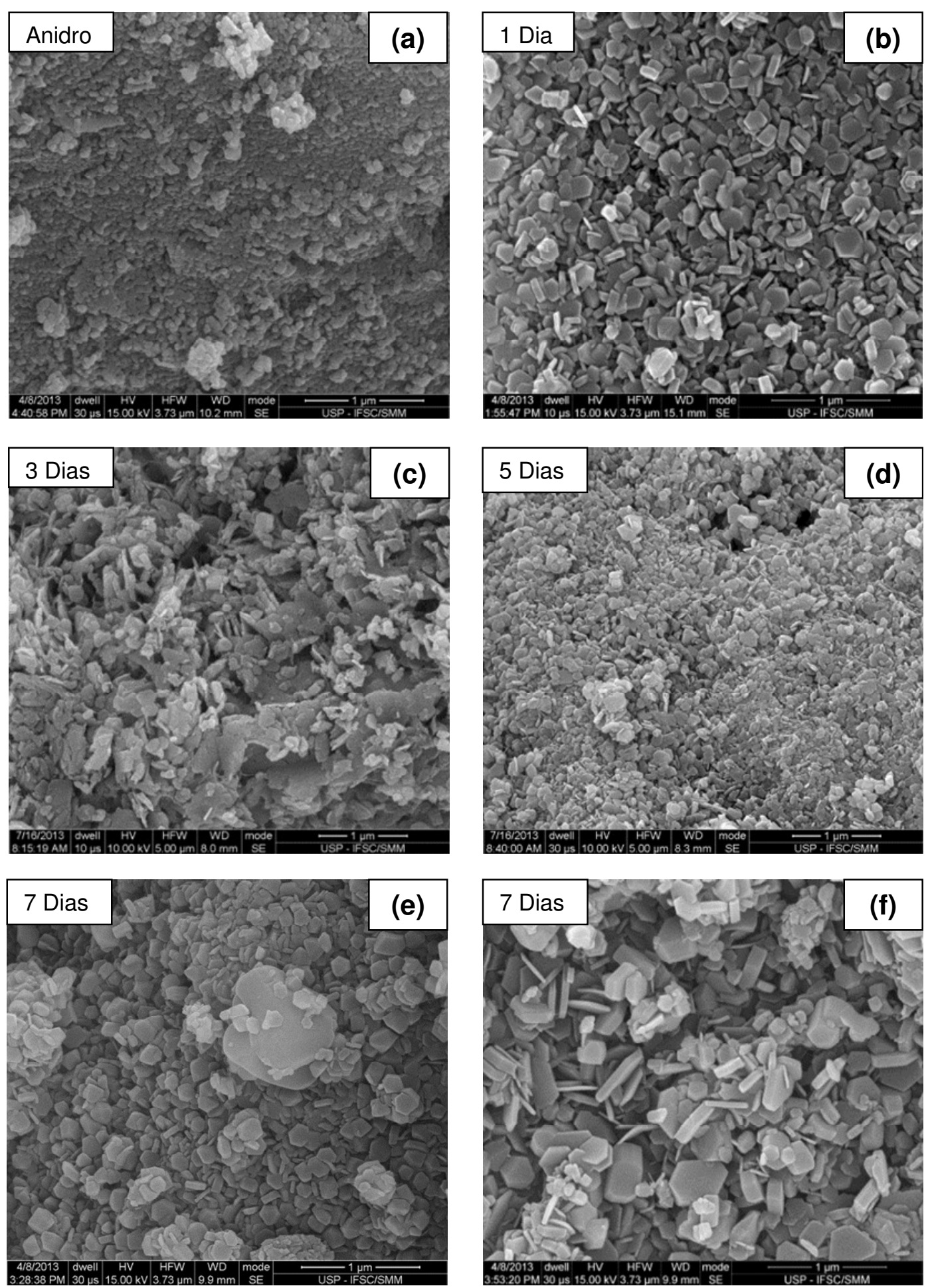

Figura 4.6 - Imagens de MEV que mostram a transformação morfológica das partículas da magnésia cáustica durante o seu processo de hidroxilação. 

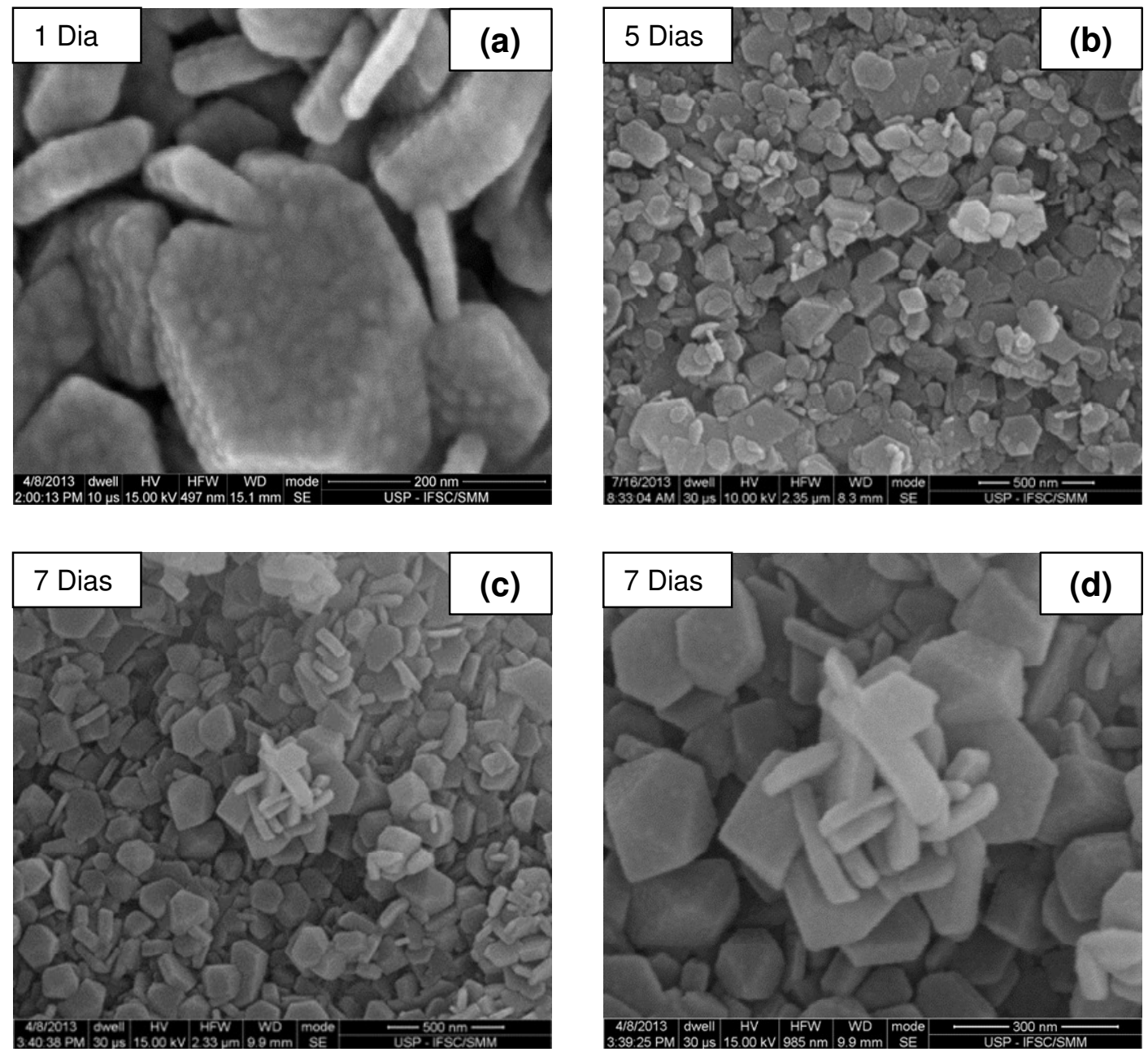

Figura 4.7 - Imagens de MEV que mostram detalhes da morfologia das partículas da magnésia cáustica durante a reação de hidroxilação na temperatura de $50^{\circ} \mathrm{C}$. 


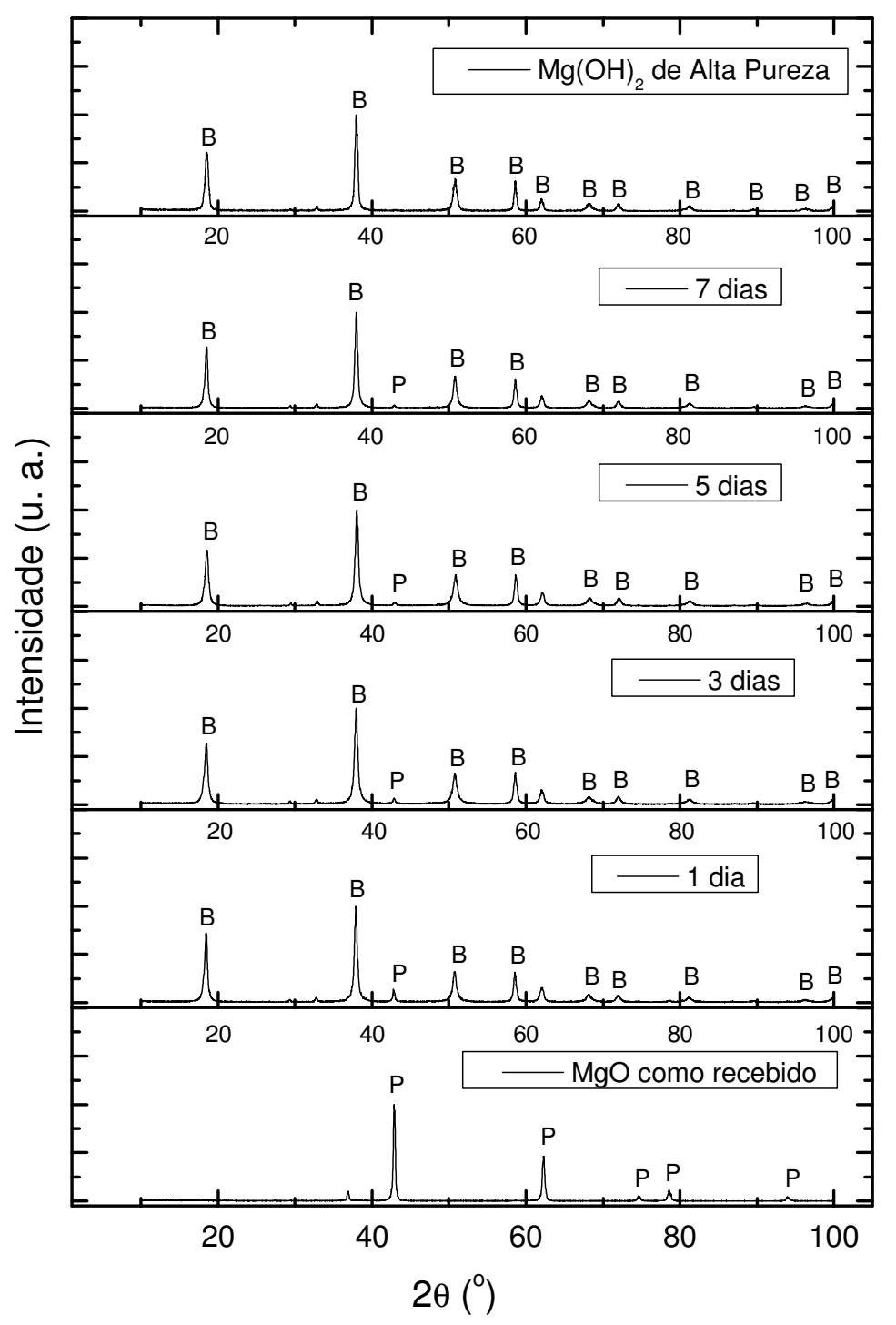

Figura 4.8 - DRX da evolução da reação de hidroxilação da magnésia cáustica, ao longo de 7 dias, a $50^{\circ} \mathrm{C}$.(P = Periclásio, JCPDS = 45-0946; B = Brucita, JCPDS = 07-0239)

\subsubsection{Densidade Real e Grau de Hidroxilação $\left(W_{H}\right)$}

$\mathrm{Na}$ Figura 4.9, tem-se o comparativo do $\mathrm{W}_{\mathrm{H}}$ com a densidade real para diferentes temperaturas nominais de teste das amostras de magnésia caustica e sínter. Nota-se uma significativa queda de densidade para as amostras hidroxiladas 
em relação ao material anidro. Embora esse efeito tenha sido descrito em outros trabalhos [39, 40], a evolução da densidade, acompanhada de forma sistêmica e metódica como registrado nesse estudo, é inédita na literatura.

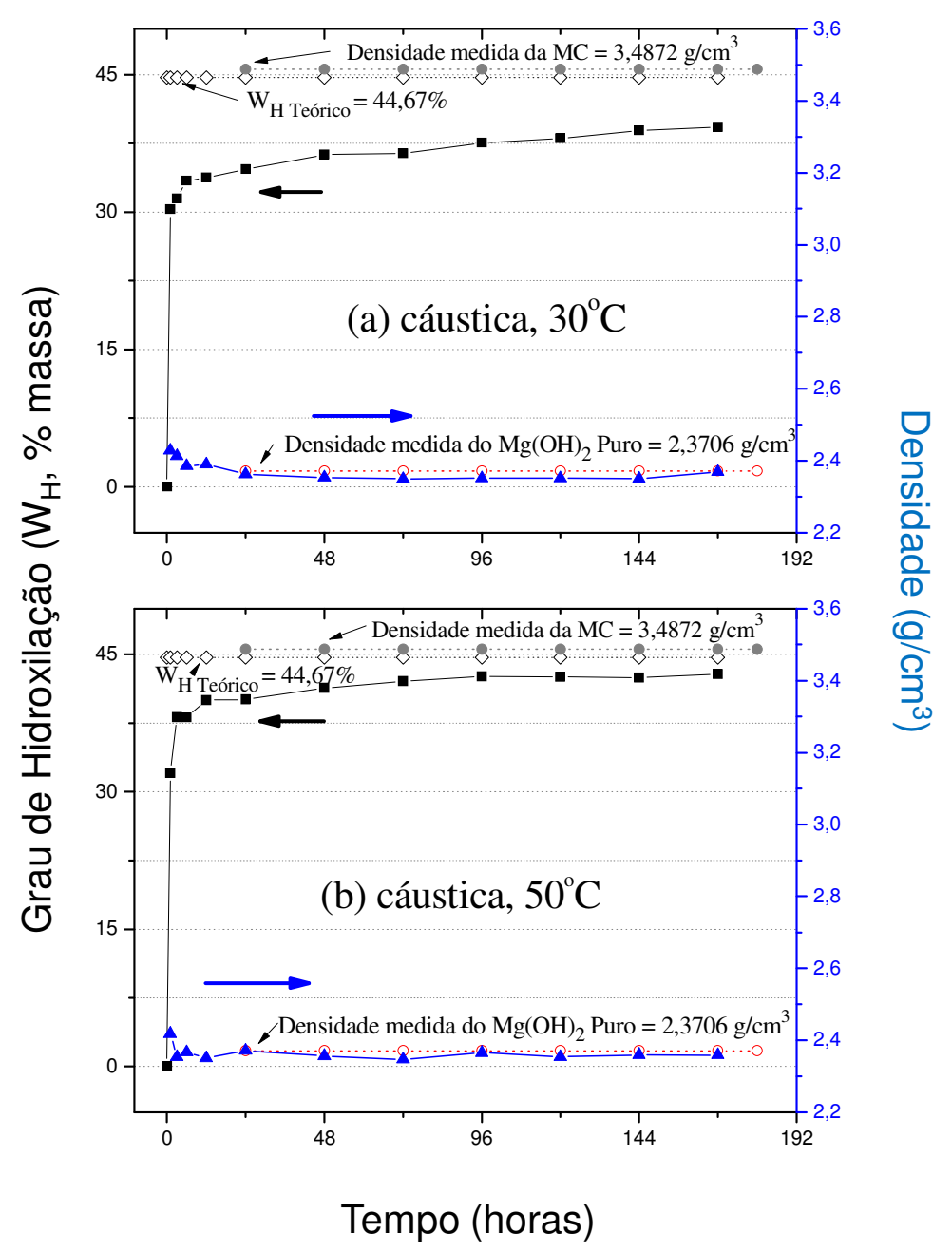

Figura 4.9 - Grau de hidroxilação e densidade do $\mathrm{MgO}$ em diferentes temperaturas nominais. a) magnésia cáustica $30^{\circ} \mathrm{C} \mathrm{e} \mathrm{b)} \mathrm{magnésia} \mathrm{cáustica}$ $50^{\circ} \mathrm{C}$. 


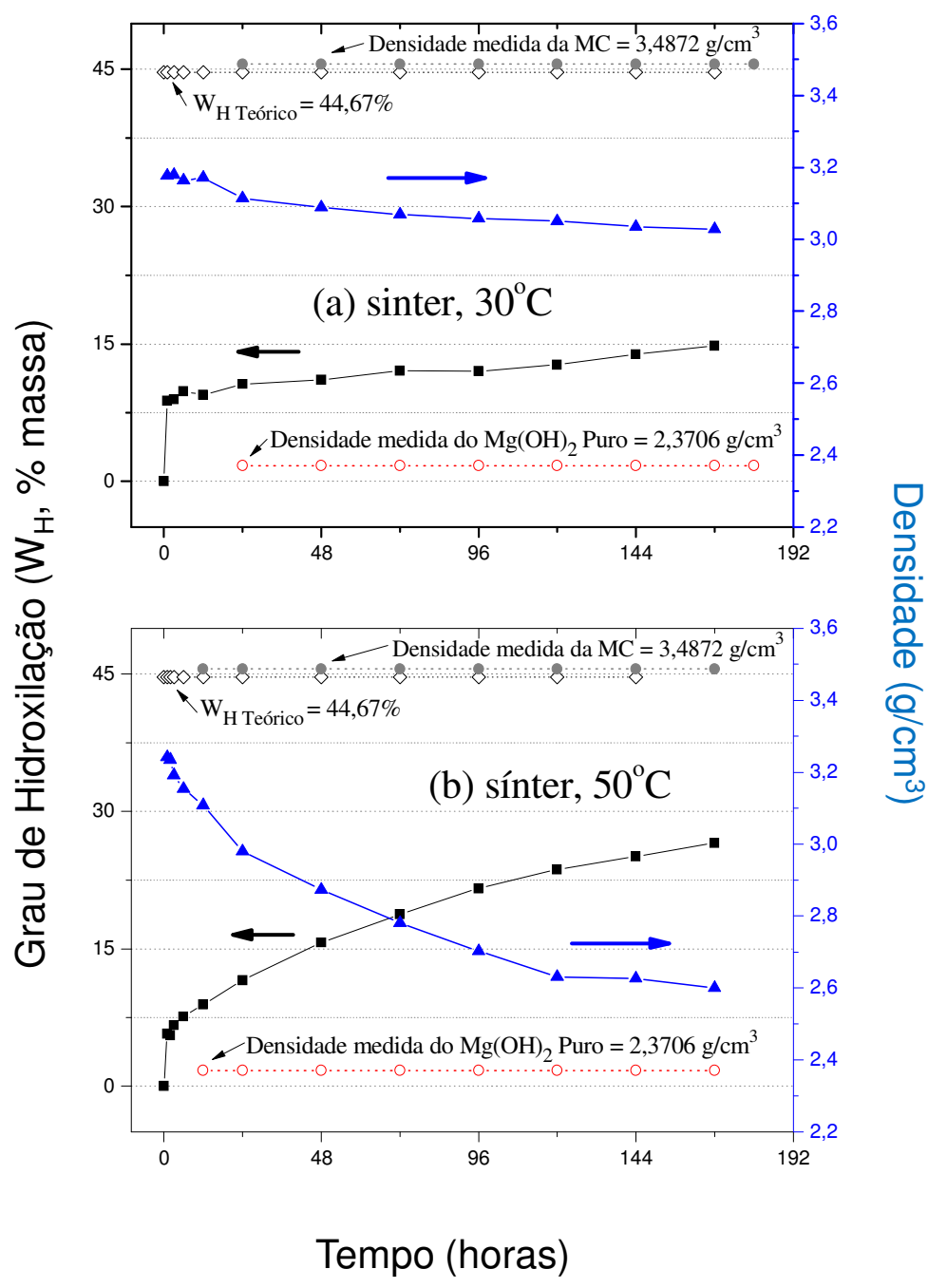

Figura 4.10 - Grau de hidroxilação e densidade do $\mathrm{MgO}$ em diferentes temperaturas nominais. a) sínter $30^{\circ} \mathrm{C} \mathrm{e} \mathrm{b)} \mathrm{sínter} 50^{\circ} \mathrm{C}(\mathrm{d})$.

Nota-se, na Figura 4.10 (a) e (b), que houve grandes variações no $W_{H}$ e na densidade para o sínter testado em diferentes temperaturas. Entretanto, para a magnésia caustica, a variação foi muito rápida nos primeiros minutos do teste. Este resultado é coerente com os dados da Tabela 4.1 e Figura 4.1 onde se observa que a caustica tem uma área superficial maior que a do sínter, facilitando a reação. 


\subsubsection{Exotermia}

Comparando-se os resultados das Figuras 4.9 e 4.10, observa-se que uma consequência da rápida reação da magnésia cáustica foi o aumento da temperatura da amostra em relação à temperatura nominal do reator. Os parâmetros ( $T_{\text {MAX }}$ ) e (TT $T_{\text {MAX }}$ ) dos gráficos (c) e (d) da Figura 4.11 deixam bem definidos as principais diferenças entre as reações de hidroxilação do sínter e da magnésia cáustica. Enquanto, a temperatura máxima obtida da reação da magnésia cáustica aumenta rapidamente a partir de $30^{\circ} \mathrm{C}$ e se estabiliza a $50^{\circ} \mathrm{C}$, a temperatura da reação do sínter apenas mantém a temperatura nominal (externa), com pequenas variações acima de $60^{\circ} \mathrm{C}$.
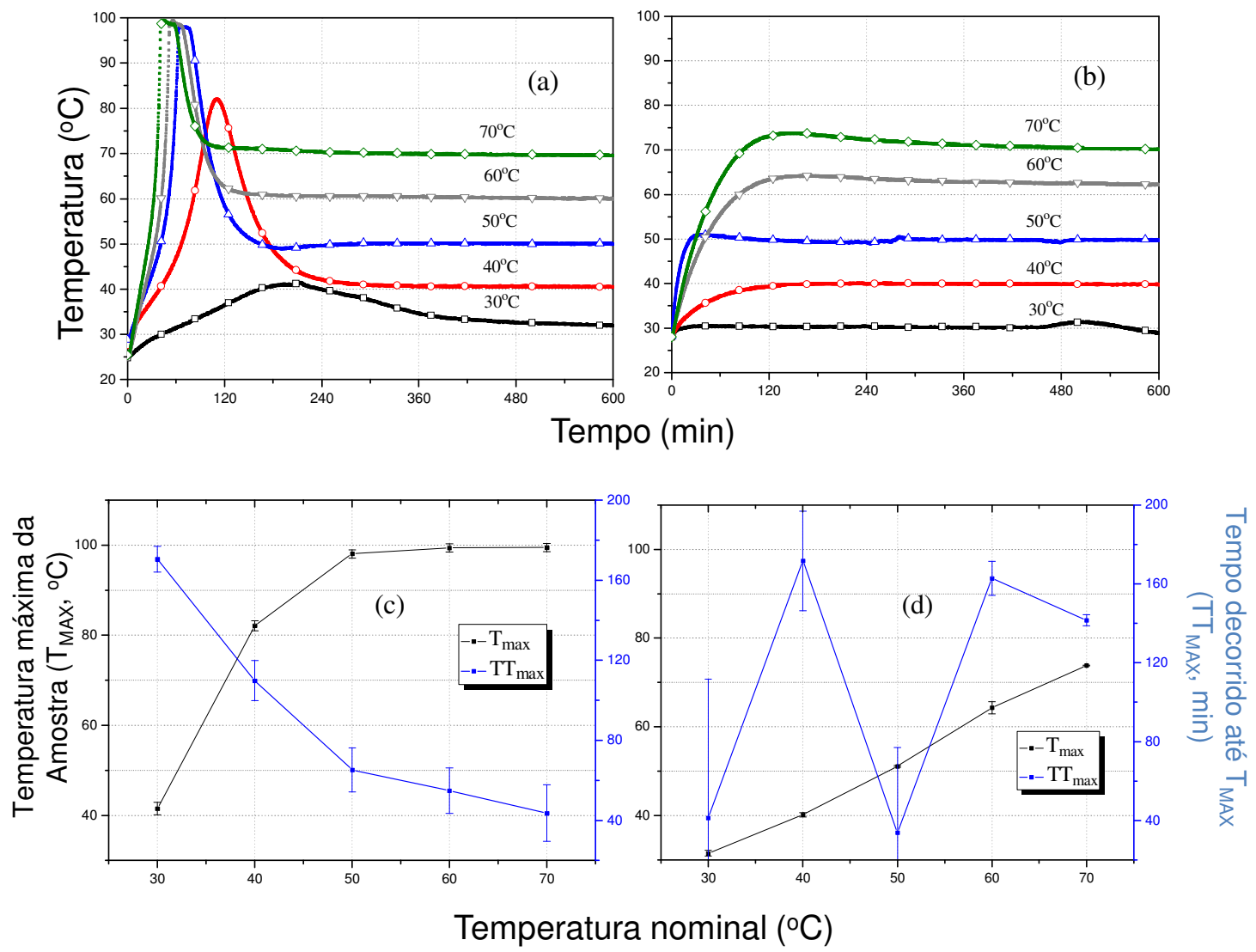

Figura 4.11 - Temperatura da amostra de $\mathrm{MgO}$ com diferentes temperaturas nominais para a magnésia cáustica (a) e para o sínter (b). Parâmetros $\mathrm{T}_{\mathrm{MAX}} \mathrm{e}$ $\mathrm{TT}_{\text {MAX }}$ para a magnésia cáustica (c) e para o sínter (d). 
Pode-se observar também que o aumento da temperatura nominal da magnésia cáustica foi acompanhado de um tempo menor para que o máximo de temperatura seja atingido. Foi observado também que a temperatura ambiente, no momento da preparação das soluções de sínter, influenciou de modo muito intenso o $\mathrm{TT}_{\text {MAX }}$ da reação de hidroxilação do sínter, causando uma grande variação observada na Figura 4.11 (d).

É importante acrescentar que os reatores utilizados não são completamente estanques e, devido a isso, parte do vapor de água formado escapou do sistema. Esse efeito pode gerar alterações ainda mais significativas na reação de hidroxilação caso um sistema hermético e hidrotermal seja utilizado. Nesse caso, temperaturas maiores que $100^{\circ} \mathrm{C}$ foram observadas [5].

\subsubsection{Resultados da Variação das Frações (\%massa) das Matérias- primas}

Em relação ao efeito do aumento da concentração de sólidos da suspensão, verificou-se que o grau de hidroxilação de ambas as matérias-primas tende a diminuir (Figura 4.12), apesar da maior exotermia das reações (Figura 4.13). Esse comportamento pode ser explicado considerando-se que, quanto maior a exotermia da reação, maior a possibilidade de evaporação de água das suspensões durante 0 teste. Esse aspecto é particularmente importante para a amostra com fração de sólidos de $69 \%$, onde a proporção água/MgO é estequiométrica para a reação. Devido a isso, qualquer quantidade de água que evapore fará diferença no processo de hidroxilação do $\mathrm{MgO}$, reduzindo seu rendimento. 


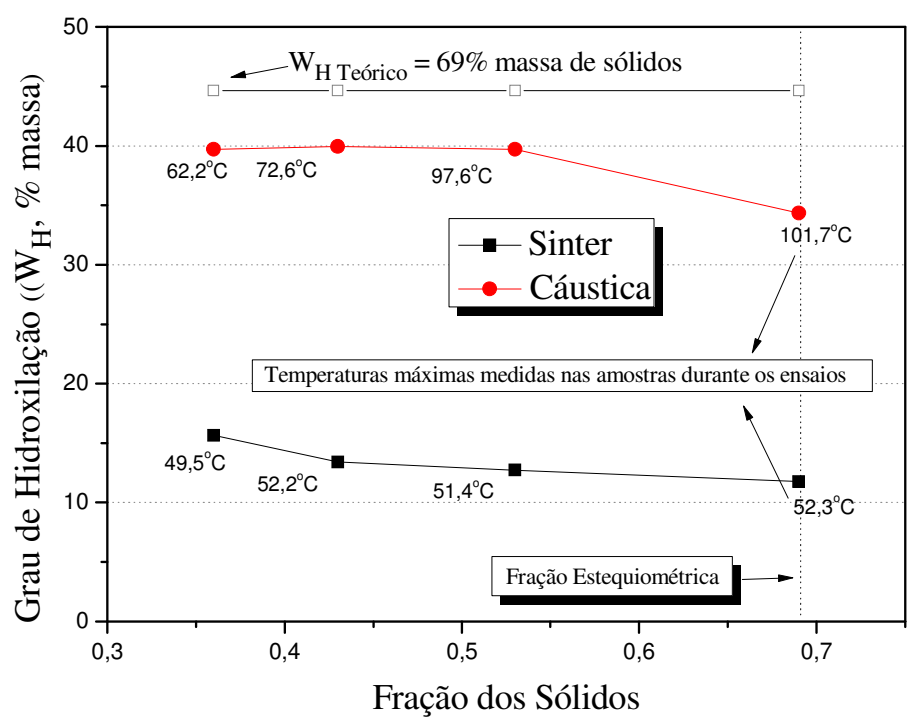

Figura 4.12 - Grau de hidroxilação do MgO para suspensões com diferentes frações de sólidos com as matérias-primas magnésia cáustica e sínter.
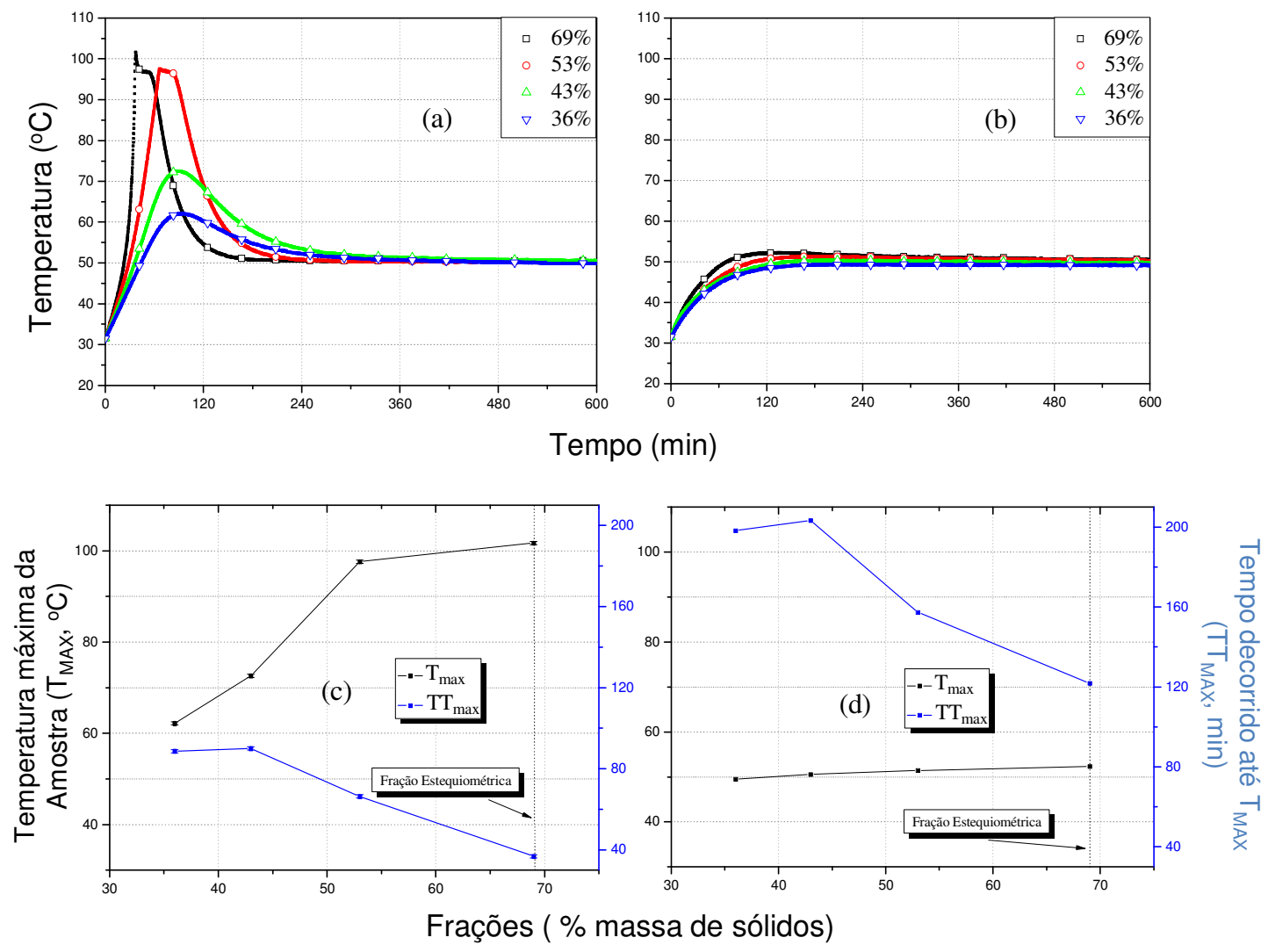

Figura 4.13 - Temperatura da amostra de MgO mantendo fixo a temperatura nominal de $50^{\circ} \mathrm{C}$, volume de $45 \mathrm{~cm}^{3}$ e o período de 1 dia, mas em diferentes frações de sólidos com as matérias-primas magnésia cáustica (a) e sínter (b). 


\subsubsection{Condutividade das Suspensões}

Na Figura 4.14 observa-se que as suspensões de sínter apresentam uma condutividade maior, no inicio da reação, quanto mais alta é a temperatura da reação, no entanto, após 1 hora de reação a condutividade diminui para as suspensões com menor temperatura. Este efeito pode estar associado à formação de brucita, que é mais solúvel em menor temperatura [17]. A inércia para que esta inversão de condutividade ocorra, se deve a dificuldade inicial da reação acontecer na superfície da partícula, pela sua baixa área de superfície específica (Tabela 4.1).

O mecanismo de rompimento das partículas [39] foi identificado nas imagens de MEV (Figura 4.4 - (c) e (d)) e nas variações observadas na temperatura de $30^{\circ} \mathrm{C}$ (Figura 4.14), pois, nota-se que a partir de 0,5 horas a suspenção aumenta a condutividade em saltos e depois se estabiliza, com tendência a diminuir.

Este efeito não é claramente identificado nas outras temperaturas, e em cada caso há uma particularidade. A $70^{\circ} \mathrm{C}$, após meia hora de reação o valor da condutividade se estabiliza, ou seja, há uma quantidade de brucita já estável, indicando que as partículas de sínter se quebraram muito rapidamente e expuseram toda a superfície (segundo a energia de ativação dada ao sistema pela temperatura de $70^{\circ} \mathrm{C}$ mantida pelo banho térmico) para que a reação ocorra. A $50^{\circ} \mathrm{C}$, há um processo semelhante a de $70^{\circ} \mathrm{C}$, contudo, a condutividade demora para se estabilizar, facilitando a formação de cristais de brucita na superfície das partículas de sínter, gerando desta forma um outro fator para a quebra das partículas de sínter. Analogamente, explica a alta condutividade da suspenção a $10^{\circ} \mathrm{C}$, sendo ainda, que a brucita se solubiliza mais facilmente a baixa temperatura [17], tem-se uma solução supersaturada, que favorece o crescimento de cristais [33, 34]. 


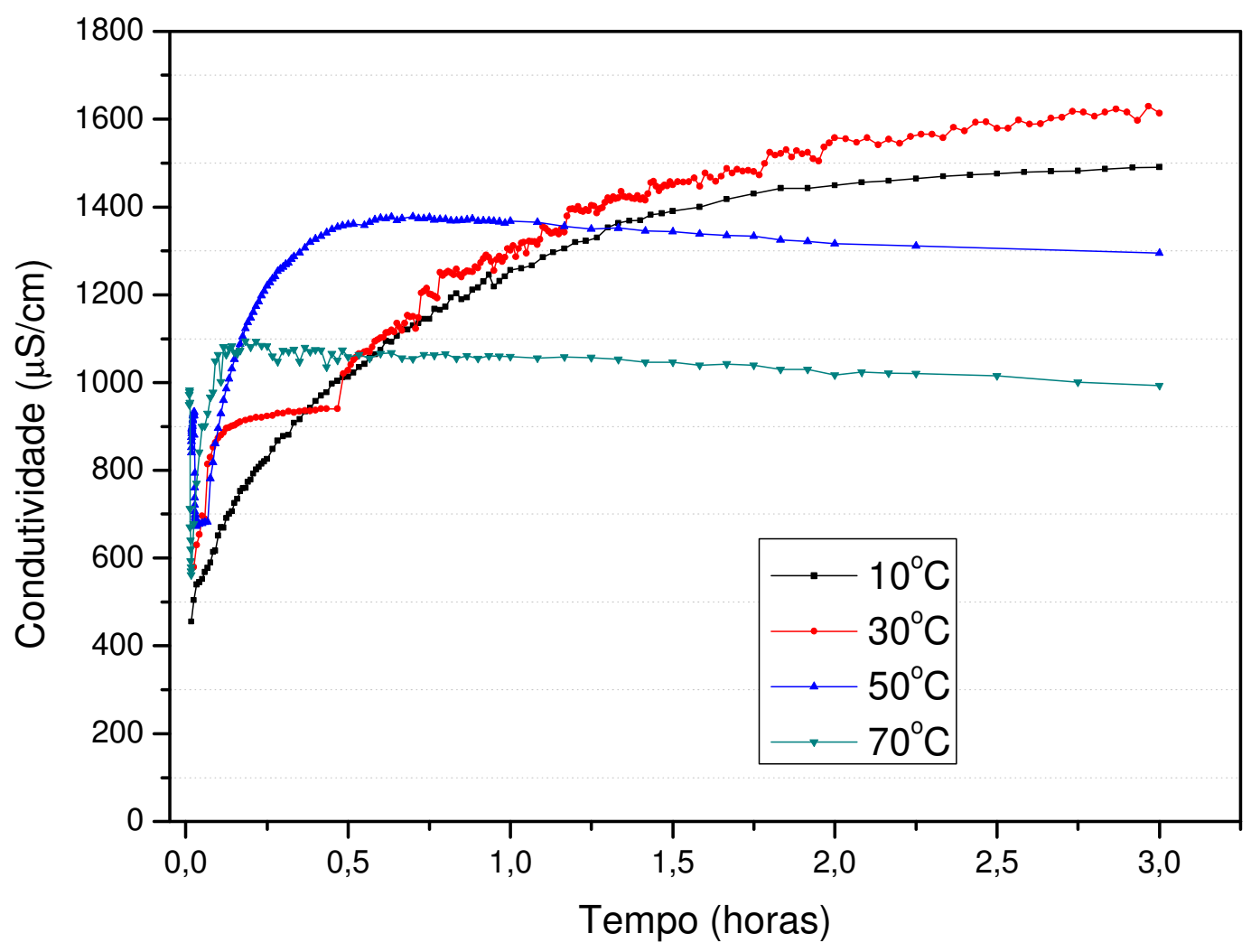

Figura 4.14 - Condutividade das suspensões do sínter em diferentes temperaturas.

As suspensões de magnésia cáustica apresentaram um comportamento diferente das suspensões do Sínter. Analisando-se a Figura 4.15 nota-se que ao invés da condutividade aumentar no decorrer da reação, como no sínter, ela cai abruptamente quanto maior a temperatura, deixando a solução menos saturada. Este resultado mostra que o crescimento de cristais do hidróxido de magnésio depende de uma solução supersaturada.

Combinando este resultado da condutividade com as imagens de MEV (Figuras 4.3, 4.4, 4.6 e 4.7), pode-se entender porque, os cristais de hidróxido formados a partir da magnésia cáustica mostram-se mais uniformes e separados. 


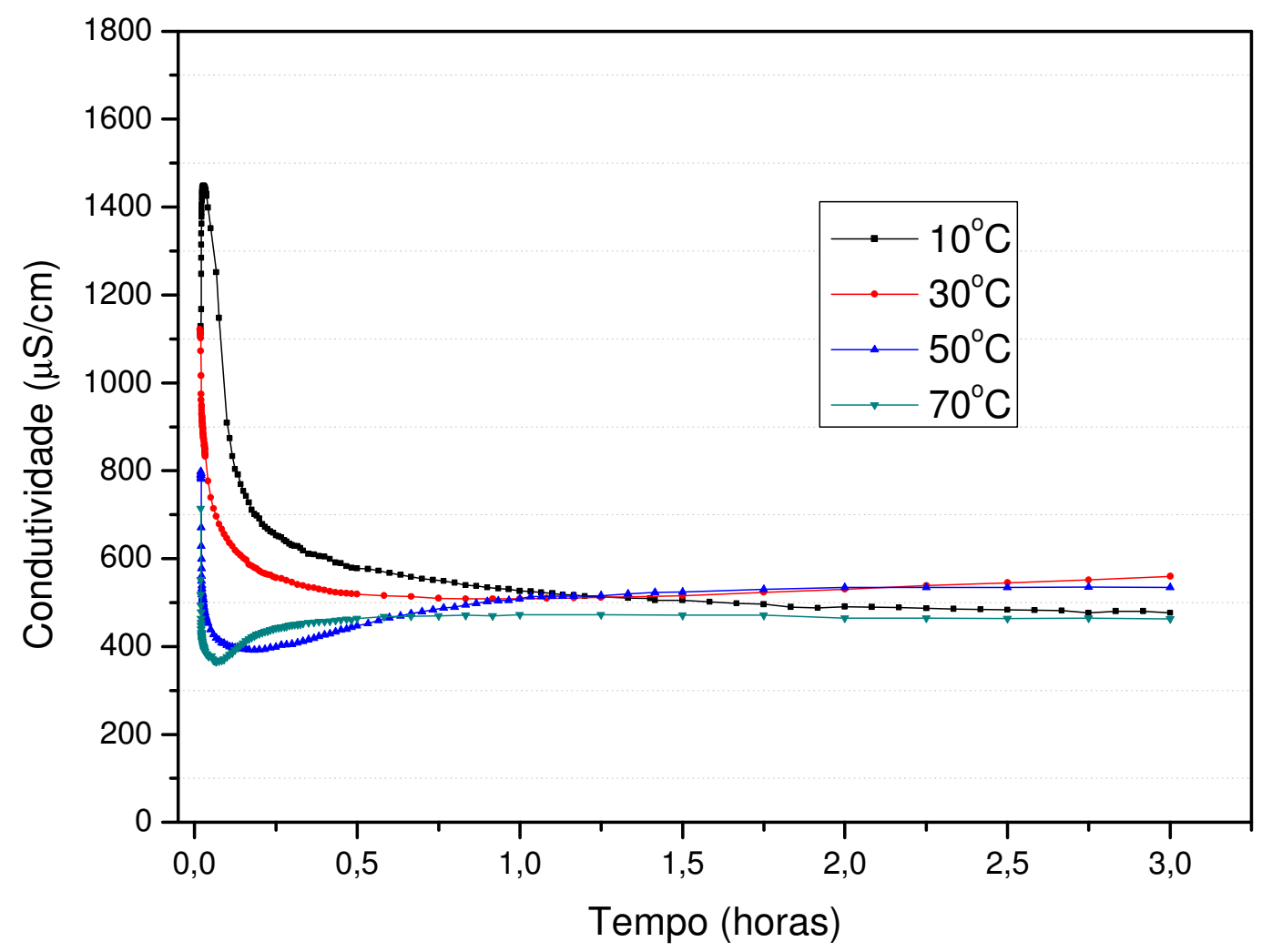

Figura 4.15 - Condutividade das suspensões da magnésia cáustica em diferentes temperaturas.

Medidas de condutividade também foram feitas para diferentes concentrações de $\mathrm{MgO}$ (Figura 4.16). Verificou-se que não houve mudança significativa de comportamento da curva de condutividade por tempo para as diferentes concentrações, entretanto, pelo aumento de solutos nas maiores concentrações provocou uma pequena diferença no valor condutividade. Esse aspecto pode ser explicado considerando-se a baixa solubilidade do $\mathrm{Mg}(\mathrm{OH})_{2}$ : como a formação de brucita depende de um passo de dissolução do $\mathrm{MgO}$, essa etapa torna-se limitante para o processo gerando concentrações de íons similares. 


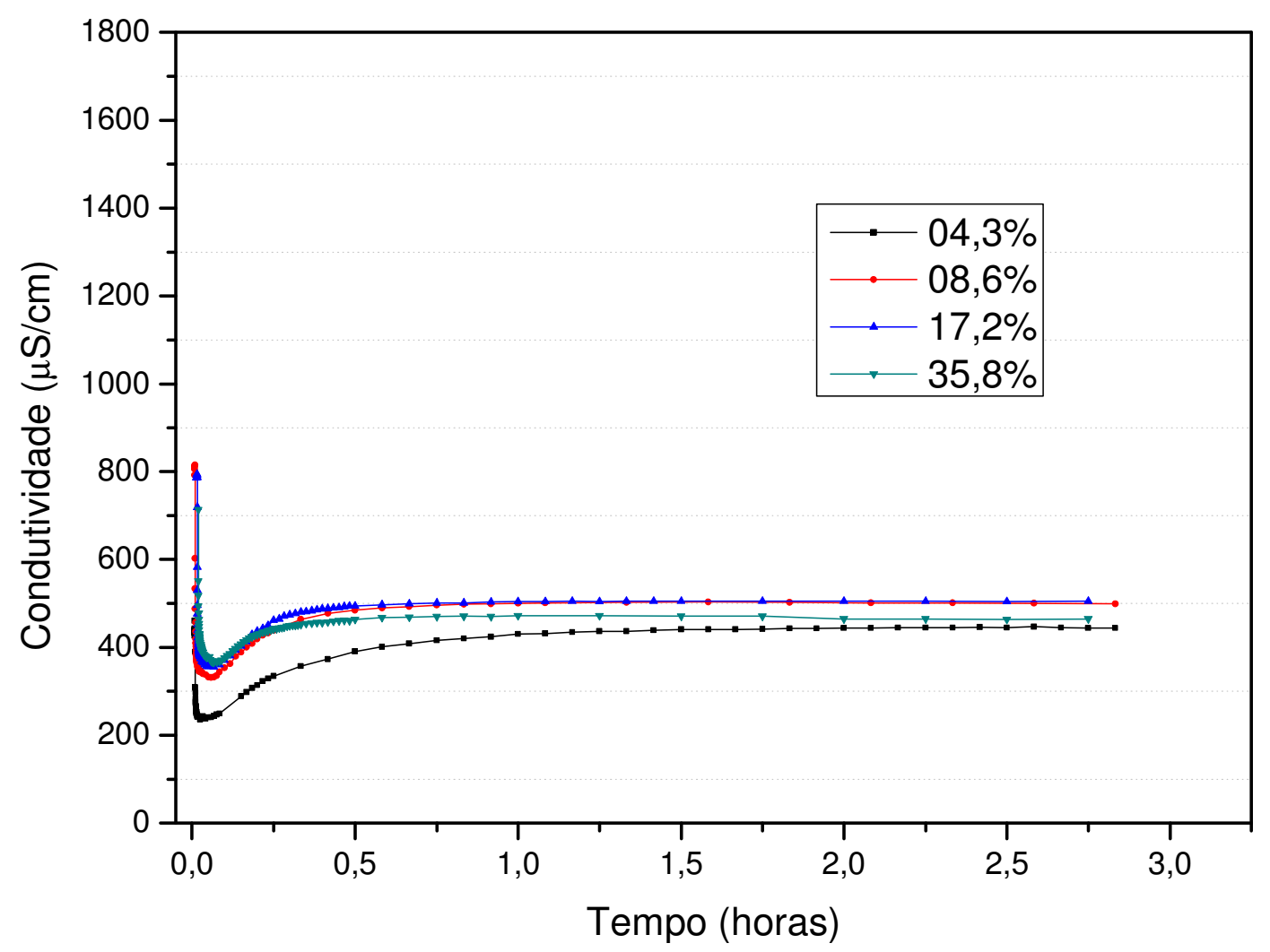

Figura 4.16 - Condutividade das suspensões da magnésia cáustica a $70^{\circ} \mathrm{C} \mathrm{em}$ diferentes concentrações de sólidos.

\subsubsection{Resultados da Variação do Volume das Amostras de Magnésia Cáustica}

A Figura 4.17 apresenta o $\mathrm{W}_{\mathrm{H}}$ para diferentes volumes das amostras em duas temperaturas nominais distintas $\left(30^{\circ} \mathrm{C}\right.$ e $\left.50^{\circ} \mathrm{C}\right)$. 


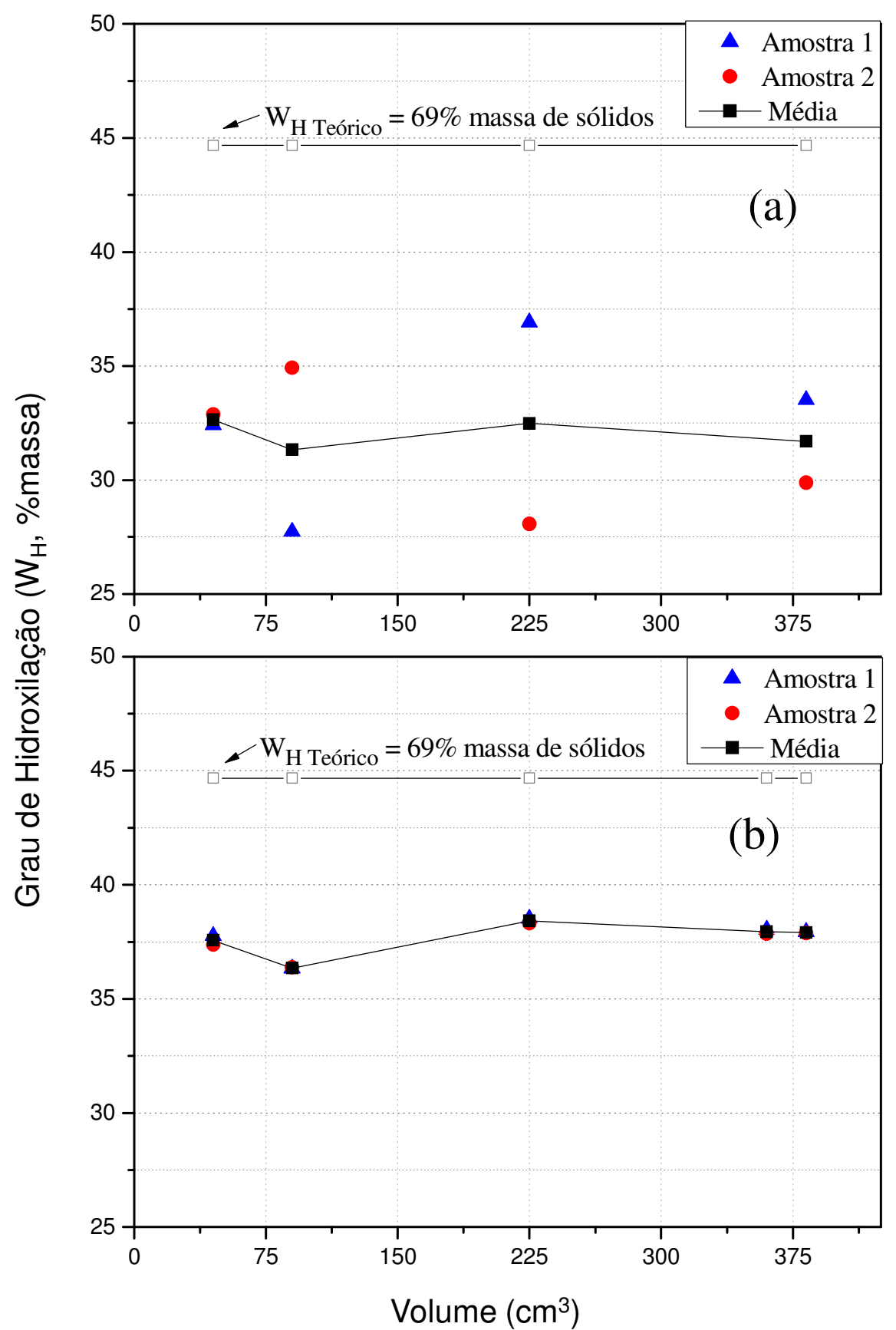

Figura 4.17 - Grau de hidroxilação do MgO (magnésia cáustica) em diferentes volumes com uma temperatura nominal de $30^{\circ} \mathrm{C}$ (a) e de $50^{\circ} \mathrm{C}(\mathrm{b})$.

Observa-se na Figura 4.17 que o aumento da temperatura dos testes (de $30^{\circ} \mathrm{C}$ para $50^{\circ} \mathrm{C}$ ) causou maiores variações nos valores médios de $W_{H}$ que a variação do volume das amostras. No entanto, para a menor temperatura de ensaio $\left(30^{\circ} \mathrm{C}\right.$, 
Figura 4.17 - (a)), houve uma maior dispersão dos valores de $\mathrm{W}_{\mathrm{H}}$ para um mesmo volume. A explicação para este resultado encontra-se na Figura 4.17 - (a) onde se observa que a temperatura da amostra foi fortemente influenciada pelo volume da amostra: quanto maior seu volume, maior a variação de temperatura em relação ao valor nominal. Já a 50ํ (Figura 4.17 - (b) e 4.18 - (b)), observa-se uma maior reprodutibilidade em termos de valor máximo de temperatura atingido e tempo para atingi-la.
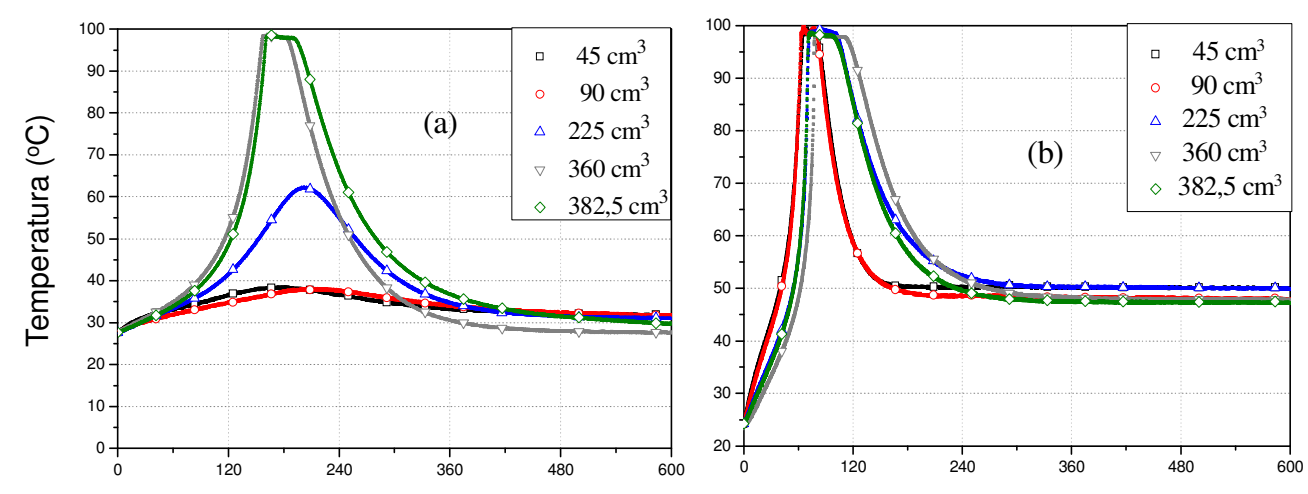

Tempo (min)

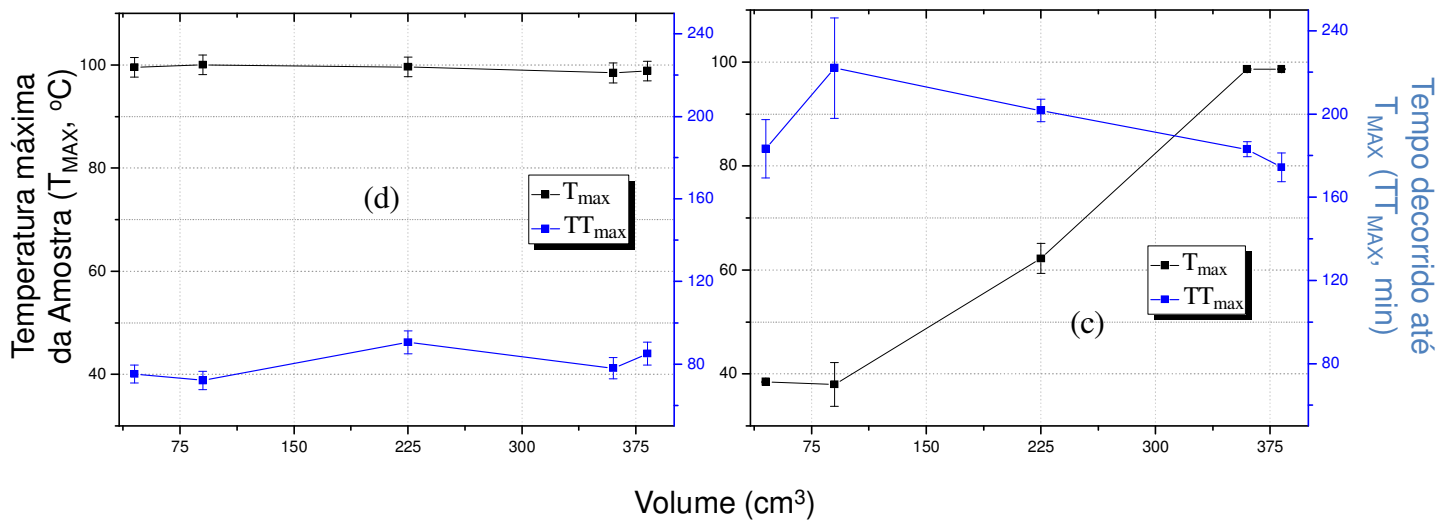

Figura 4.18 - Temperatura da amostra de MgO (magnésia cáustica) em diferentes volumes com uma temperatura nominal de $30^{\circ} \mathrm{C}$ (a) e de $50^{\circ} \mathrm{C}$ (b). Parâmetros $\mathrm{T}_{\text {MAX }}$ e $\mathrm{TT}_{\text {MAX }}$ em diferentes volumes com uma temperatura nominal de $30^{\circ} \mathrm{C}$ (c) e de $50^{\circ} \mathrm{C}$ (d) 


\section{CONCLUSÕES}

Este trabalho investigou as principais variáveis intrínsecas e externas envolvidas no processo de hidroxilação do oxido de magnésio (MgO).

Verificou-se que a alteração da fonte de MgO (sínter ou magnésia caustica) foi o fator que mais intensamente afetou sua reatividade química, cinética de hidroxilação, bem como a morfologia do produto formado. De forma geral, a magnésia caustica apresentou maior reatividade que o sínter, como demonstrado pelas medidas de grau de hidroxilação, densidade e difração de raios X. Esse fato foi associado à sua maior área superficial específica $\left(17 \mathrm{~m}^{2} / \mathrm{g}\right.$ em relação a $1,5 \mathrm{~m}^{2} / \mathrm{g}$ do sínter), à presença de quantidade significativa de microporos nas partículas (oriundas da etapa de calcinação) e, em alguns, casos da intensa liberação de calor da própria reação. Em relação ao mecanismo de hidroxilação, as medidas de condutividade iônica de suspensões aquosas revelaram que para a magnésia caustica a dissolução e o inicio da precipitação do $\mathrm{Mg}(\mathrm{OH})_{2}$ ocorrem quase que instantaneamente após o contato com a agua, sendo pouco afetada pela temperatura. Já para o sínter, observou-se um período de indução onde ocorre a dissolução do material seguido da precipitação do $\mathrm{Mg}(\mathrm{OH})_{2}$ de forma mais lenta que para a magnésia cáustica. Finalmente, em relação ao produto formado, em ambos os casos somente $\mathrm{Mg}(\mathrm{OH})_{2}$ foi observado. Para o sínter, observou-se uma fragmentação inicial das partículas de $\mathrm{MgO}$ nos primeiros dias de hidroxilação. Em seguida, observou-se uma estrutura mais compacta com cristais hexagonais maiores crescidos na superfície das partículas de MgO.

Em relação às variáveis externas, foram avaliados o efeito combinado do tempo e temperatura do meio reacional, da exotermia da reação e do volume e concentração de sólidos das amostras.

Para a magnésia cáustica, a liberação de calor ocorrida durante a própria reação afetou consideravelmente sua cinética de hidroxilação. Para experimentos conduzidos em temperatura nominal entre $50-70^{\circ} \mathrm{C}$ temperaturas próximas de $100^{\circ} \mathrm{C}$ foram observadas dentro das amostras. Esse efeito fez com que os valores de grau 
de hidroxilação medidos nessas condições fossem bastante próximos, independentemente dos parâmetros de tempo e temperatura utilizados. Verificou-se que esse efeito da exotermia pode ser particularmente intenso em amostras de maior volume (entre 225 e 382,5 cm ch $^{3}$, devido à dificuldade de se manter ou retirar calor. Nesses casos, embora o grau de hidroxilação tenha se mantido aproximadamente constante, amostras de maior volume apresentaram maior variabilidade. A variação da fração de sólidos das suspensões em relação ao teor de água estequiométrico para a reação não afetou significativamente o grau de hidroxilação(exceto para a composição estequiométrica, onde parte da água evaporou durante a liberação de calor e reduziu o rendimento da reação.)Por outro lado, para as suspensões com menor teor de solido, a presença de grande quantidade de água reduziu o efeito do aquecimento interno, minimizando a variabilidade dos testes.

O sínter mostrou-se menos susceptível a essas variáveis. Como não se observou geração significativa de aquecimento interno, a cinética da reação foi fortemente dependente das condições nominais de temperatura e tempo de reação.

A partir desses resultados, sugere-se que, para que a reação de hidroxilação do MgO ocorra de forma intensa e eficiente, sejam utilizados o seguintes parâmetros: 1) suspensões aquosas de magnésia cáustica com concentração de sólidos próxima à estequiométrica (69\%massa), 2) mantida em um reator com temperatura acima de $50^{\circ} \mathrm{C}, 3$ ) com grande volume (acima de $225 \mathrm{~cm}^{3}$ ) e 4) se possível, com isolamento térmico para que o aumento da temperatura interna catalise a reação. Considerando que se deseja obter testes de hidroxilação mais reprodutíveis e com menor variabilidade, recomenda-se utilizar: 1) suspensões aquosas com baixa fração de sólidos (abaixo de 53 \%massa), 2) em temperaturas não superiores a $50^{\circ} \mathrm{C}$ e 3 ) volumes reduzidos. 


\section{REFERÊNCIAS ${ }^{1}$}

1) HORNSBY, P. R. (1994). The application of magnesium hydroxide as a fire retardant and smoke-suppressing additive for polymers. Fire and Materials, 18,p. 269-276.

2) VERMILEYA, D. A. (1969). The Dissolution of $\mathrm{MgO}$ and $\mathrm{Mg}(\mathrm{OH})_{2}$ in Aqueous Solutions. Journal of The Electrochemical Society, p. 1179-1183.

3) NISHIKAWA, A. (1984). Technology of monolithic refractories. Technical Report, 33, p. 98-101.

4) LAYDEN, G. K.; BRINDLEY, G. W. (1963). Kinetics of vapor-phase hydration of magnesium oxide. Journal of the American Ceramic Society, 46 , p. $518-522$.

5) KITAMURA, K.; ONIZUKA, K.; TANAKA, K. (1965) Hydration characteristics of magnesia. Taikabutsu Overseas, 16, p. 3-11.

6) BITTENCOURT, L. D. M. (1995). Densification and Grain Cowth of a Refractory Grade Magnesia Derived from Magnesite. Dissertation. University of Missouri, Rolla, MO.

7) BRATTON, R. J.; BRINDLEY, C. W. (1965). Kinetics of vapour Phase Hydration of Magnesium Oxide Part 2 - Dependence on temperature and water vapour pressure. Transactions of the Faraday Society, 61, p. 10171025.

8) CANTERFORD, I. H. (1985). An Important Industrial Mineral: A Review of Processing Options and Uses. Mineral Processing and Extractive Metallurgy Review 2, p. 57-104.

9) FEITKNECHT, W.; BRAUN, H. (1967). Der mechanisms der hydration von magnesiumoxid mit wasserdampf. Helvetica Chimica Acta, 50, p. 20402053.

10) SMITHSON, C. L.; BAKHSHI, N. N. (1969). The Kinetics and Mechanism of the Hydration of Magnesium Oxide in a Batch Reactor. The Canadian Journal of Chemical Engineering, 47, p. 508-513.

11) HIMMELBLAU, D. M. (1972). Applied Non-linear Programming. New York: McCraw-Hill, p. $213 .^{1}$

${ }^{1} 1$ - De acordo com a Associação Brasileira de Normas Técnicas. NBR 6023. 
12) LAYDEN, C. L.; BRINDLEY, C. W. (1963). Kinetics of Vapour-Phase Hydration of Magnesium Oxide. Journal of the American Ceramic Society, 46 , p. $518-522$.

13) ROCHA, S. D. (1997). Cinética e mecanismo da hidratação da magnésia e utilização do hidróxido de magnésio como retardante de chama para poliamida 6-6,6. PhD Thesis. Departamento de Engenharia Metalúrgica e de Minas, UFMG, Belo Horizonte, MG, Brazil.

14) SMITHSON, C. L.; BAKHSHI N. N. (1969). The Kinetics and Mechanism of the Hydration of Magnesium Oxide in a Batch Reactor. The Canadian Journal of Chemical Engineering, 47, p. 508-513.

15) ZETTLEMOYER A.C.; WALKER, W. C. (1947). Active Magnsia Surface- Surface áreas and Pore Structure from Nitrogen Adsorption. Ceramic Abstracts, Oct., p. 209b.

16) KANEYASU, A.; YAMAMOTO, S.; YOSHIDA, A. (1996). Magnesia raw materials with improved hydration resistance. Taikabutsu Overseas, 17, $\mathrm{p}$. 21-26.

17) ROCHA, S. D. F.; MANSUR, M. B.; CIMINELLI, V. S. T. (2004) Kinetics and mechanistic analysis of caustic magnesia hydration. Journal of Chemical Technology and Biotechnology, 79, p. 816-821.

18) BRANDÃO, P. R. G.; GONÇALVES, G. E.; MORATO, A. G. (2003) Mechanisms of Hydration/Carbonation of. Magnesia Sinters - Part III. Refractories Applications News, 8, p. 23-26.

19) JANOWSKI, K. R.; ROSSI, R. C. (1968). Mechanical Degradation of $\mathrm{MgO}$ by Water Vapor. Journal of the American Ceramic Society, 51, p. 453455.

20) WOGELIUS, R. A.; REFSON, K.; FRASER, D. G.; GRIME, G. W.; GOFF, J. P. (1995). Periclase surface hydroxylation during dissolution. Geochimica et Cosmochimica Acta, 59, p. 1875-1881.

21) BIRCHAL, V. S. S.; ROCHA, S. D. F.; CIMINELLI, V. S. T. (2000). The effect of magnesia calcination conditions on magnesia hydration. Minerals Engineering, 13, p. 1629-1633.

22) ANDERSON, P. J.; HORLOCK, R. F.; OLIVER, J. F. (1965). Interaction of Water with the Magnesium Oxide Surface. Transactions of the Faraday Society, 61, p. 2754-2762. 
23) BIRCHAL, V. S.; ROCHA, S. D. F.; MANSUR, M. B.; CIMINELLI, V. S. T. (2001). A simplified mechanistic analysis of the hydration of magnesia. The Canadian Journal of Chemical Engineering, 79, p. 507-511.

24) AMARAL, L. F.; SALOMÃO, R.; FROLLINI, E.; PANDOLFELLI, V. C. (2008). Efeito do íon comum na reação de hidratação do MgO. Cerâmica, 54, p. $49-54$.

25) BIRCHAL, V. S. S.; ROCHA, S. D. F.; CIMINELLI, V. S. T. (2000). The Effect of Magnesite Calcination Conditions on Magnesia Hydration. Minerals Engineering, 13, p. 14-15.

26) EUBANK, W. R. (1951). Calcination Studies of Magnesium Oxides. Journal of The American Ceramic Society, 34, p. 225-229.

27) CANTERFORD, I.H. (1985). An Important Industrial Mineral: A Review of Processing Options and Uses. Mineral Processing and Extractive Metallurgy Review 2, 57-104.

28) SMITHSON, C. L.; BAKHSHI N. N. (1969). The Kinetics and Mechanism of the Hydration of Magnesium Oxide in a Batch Reactor. The Canadian Journal of Chemical Engineering, 47, p. 508-513.

29) BRANDÃO, P.; GONÇALVES, G. E.; DUARTE, A. K. (1998). Mechanisms of Hydration/Carbonation of Basic Refractories - Part I. Refractories Applications News, 3, p. 6-9.

30) BRANDÃO, P.; GONÇALVES, G. E.; DUARTE, A. K. (1998). Mechanisms of Hydration/Carbonation of Basic Refractories - Part II: Investigation of the Kinetics of Formation of Brucite in Fired Basic Bricks. Refractories Applications News, 3, p. 9-11.

31) BRANDÃO, P.; GONÇALVES, G. E.; DUARTE, A. K. (1998). Mechanisms of Hydration/Carbonation of Basic Refractories - Part III. Refractories Applications News, 8, p. 23-26.

32) CHATTERJI, S. (1995). Mechanism of Expansion of Concrete due to the Presence of Dead-Burnt $\mathrm{CaO}$ and $\mathrm{MgO}$. Cement and Concrete Research, 25, p. 51-56.

33) CHATTERJI, S. (2005). Aspects of generation of destructive crystal growth pressure. Journal of Crystal Growth, 277, p. 566-577.

34) FLATT, R. J. (2002). Salt damage in porous materials how high supersaturations are generated. Journal of Crystal Growth, 242, p. 435-454. 
35) CHATTERJI, S.; THAULOW, N. (1997). Unambiguous Demonstration of Destructive Crystal Growth Pressure. Cement and Concrete Research, 27, p. 811-816.

36) HOLLOWAY, L. R. (1987). Application of magnesium hydroxide as a flame retardant and smoke supressant in elastomers. Rubber Chemical Technology, 61, p. 186-193.

37) ROCHA, S. D. F.; CIMINELLI, V. S. T. (2001). Utilization of magnesium hydroxide produced by magnesium hydration as fire retardant for nylon 6-6,6. Polímeros: Ciência e Tecnologia, 11, p. 116-120.

38) FILLIPOU, D.; KATIFORIS, N.; PAPASSIOPI, N.; ADAM, K. (1999). On the kinetics of magnesia hydration in magnesium acetate solutions. Journal Chemical Technology of Biotechnology, 74, p. 322-338.

39) SALOMÃO, R.; BITTENCOURT, L. R. M.; PANDOLFELLI, V. C. (2006). Aspectos da hidratação de óxido de magnésio em formulações de concretos refratários. Cerâmica, 52, p. 146-150.

40) AMARAL, L. F.; SALOMÃO, R.; FROLLINI, E.; PANDOLFELLI, V. C. (2007). Mecanismos de hidratação do óxido de magnésio. Cerâmica, 53, p. 368-372.

41) SALOMÃO, R.; PANDOLFELLI V. C. (2005). Magnesia Containing Refractory Castables (MCRF): na Overview of 30 years of research and development. Submetido para publicação no American Ceramic Society Bulletin.

42) YOSCHIDA, A.; NEMOTO, T.; KANEYASU, A. (2003). Evaluation Method for Hydration Resistance of Magnesia Fine Powder and Effect of $\mathrm{B}_{2} \mathrm{O}_{3}$ Content in Magnesia Raw Materials. Proceeding of UNITECR' 03, Osaka, 433-436.

43) ZHANG, S.; HASHIMOTO, S.; LEE, W. E. (2003) Inhibiting Hydration of Aluminum Powder Using $\mathrm{SiO}_{2}$ Coatings. Refractories Applications News, 8, p. 21-25.

44) STUDART, A.; INNOCENTINI, M. D. M.; OLIVEIRA, I. R.; PANDOLFELLI, V. C. (2005) Reaction of Aluminum Powder with Water in Cement-Containing Refractory Castables. Journal of the European Ceramic Society, 25, p. 3135-3143. 
45) VEDDER, W.; VERMILYEA, D. A. (1969). Aluminum + water reaction. Transactions. Faraday Society, 65, p. 561-584.

46) BALL, M. C.; TAYLOR, H. F. W. (1961). The dehydration of brucite. Mineralogical Society, Jan., p. 754-766. 